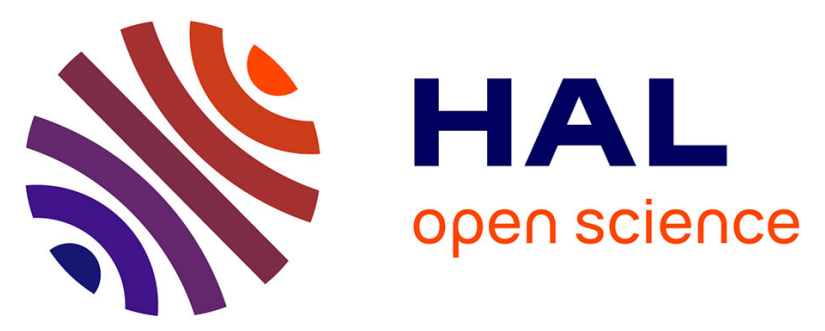

\title{
Spatial and temporal patterns of exhumation across the Venezuelan Andes: Implications for Cenozoic Caribbean geodynamics
}

\author{
Mauricio A. Bermúdez, Barry P. Kohn, Peter A. van Der Beek, Matthias \\ Bernet, Paul B. O'Sullivan, Reginald Shagam
}

\section{To cite this version:}

Mauricio A. Bermúdez, Barry P. Kohn, Peter A. van Der Beek, Matthias Bernet, Paul B. O'Sullivan, et al.. Spatial and temporal patterns of exhumation across the Venezuelan Andes: Implications for Cenozoic Caribbean geodynamics. Tectonics, 2010, 29 (5), pp.TC5009. 10.1029/2009TC002635. insu-00549245

\section{HAL Id: insu-00549245 \\ https://hal-insu.archives-ouvertes.fr/insu-00549245}

Submitted on 12 Aug 2021

HAL is a multi-disciplinary open access archive for the deposit and dissemination of scientific research documents, whether they are published or not. The documents may come from teaching and research institutions in France or abroad, or from public or private research centers.
L'archive ouverte pluridisciplinaire HAL, est destinée au dépôt et à la diffusion de documents scientifiques de niveau recherche, publiés ou non, émanant des établissements d'enseignement et de recherche français ou étrangers, des laboratoires publics ou privés.

$$
\text { Copyright }
$$




\title{
Spatial and temporal patterns of exhumation across the Venezuelan Andes: Implications for Cenozoic Caribbean geodynamics
}

\author{
Mauricio A. Bermúdez, ${ }^{1,2}$ Barry P. Kohn, ${ }^{3}$ Peter A. van der Beek, ${ }^{1}$ Matthias Bernet, ${ }^{1}$ \\ Paul B. O’Sullivan, ${ }^{4}$ and Reginald Shagam ${ }^{5,6}$ \\ Received 27 November 2009; revised 28 April 2010; accepted 18 May 2010; published 17 September 2010.
}

[1] The Venezuelan Andes formed by complex geodynamic interaction between the Caribbean Plate, the Panamá Arc, the South American Plate and the continental Maracaibo block. We study the spatial and temporal patterns of exhumation across the Venezuelan Andes using 47 new apatite fission track (AFT) ages as well as topographic analyses. This approach permits the identification of at least seven tectonic blocks (Escalante, Cerro Azul, Trujillo, Caparo, Sierra Nevada, Sierra La Culata and El Carmen blocks) with contrasting exhumation and cooling histories. The Sierra Nevada, Sierra La Culata and El Carmen blocks, located in the central part of the Venezuelan Andes and separated by the Boconó fault system, cooled rapidly but diachronously during the late MiocenePliocene. Major surface uplift and exhumation occurred in the Sierra Nevada block since before $8 \mathrm{Ma}$. A second phase of uplift and exhumation affected the El Carmen and Sierra La Culata blocks to the north of the Boconó fault during the late Miocene-Pliocene. The highest topography and steepest relief of the belt coincides with these blocks. The Caparo and Trujillo blocks, located at the northeastern and southwestern ends of the orogen, cooled more slowly from the Oligocene to the late Miocene. These blocks are characterized by significantly lower mean elevations and slightly lower mean slopes than the central blocks. Unraveling the cooling history of the individual blocks is important to better understand the control of preexisting faults and regional Caribbean geodynamics on the evolution of the Venezuelan Andes. Our data indicate a strong control of major preexisting fault zones on

\footnotetext{
${ }^{1}$ Laboratoire de Géodynamique des Chaînes Alpines, Université Joseph Fourier, Grenoble, France.

${ }^{2}$ Laboratorios de Termocronología y Geomatemáticas, Escuela de Geología, Minas y Geofísica Facultad de Ingeniería, Universidad Central de Venezuela, Caracas, Venezuela.

${ }^{3}$ School of Earth Sciences, University of Melbourne, Melbourne, Victoria, Australia.

${ }^{4}$ Apatite to Zircon, Inc., Viola, Idaho, USA.

${ }^{5}$ Geological and Environmental Sciences, Ben-Gurion University of the Negev, Beer Sheva, Israel.

${ }^{6}$ Deceased 19 April 2008.

Copyright 2010 by the American Geophysical Union. 0278-7407/10/2009TC002635
}

exhumation patterns and temporal correlation between phases of rapid exhumation in different blocks with major tectonic events (e.g., collision of the Panamá arc; rotation of the Maracaibo block). Citation: Bermúdez, M. A., B. P. Kohn, P. A. van der Beek, M. Bernet, P. B. O'Sullivan, and R. Shagam (2010), Spatial and temporal patterns of exhumation across the Venezuelan Andes: Implications for Cenozoic Caribbean geodynamics, Tectonics, 29, TC5009, doi:10.1029/2009TC002635.

\section{Introduction}

[2] The Venezuelan Andes form a complex orogen characterized by high seismicity and localized rapid Neogene exhumation [Kohn et al., 1984; Case et al., 1990]. This northeast trending orogen constitutes the northwestern termination of the stable South American plate [Colletta et al., 1997], extending $400 \mathrm{~km}$ from the Colombia-Venezuela border to south of Barquisimeto (Figures 1 and 2). The Venezuelan or Mérida Andes were formed as a result of oblique convergence between the Caribbean and South American plates, accretion of the Panamá arc, and rotation and translation of the continental Maracaibo block [Aleman and Ramos, 2000; Pindell and Kennan, 2001]. The reactivation of preexisting tectonic discontinuities of different ages and origins, mostly developed along the former passive margin of the South American plate, has played an important role in the evolution of the orogen [Jacques, 2004; Mora et al., 2009]. Oblique plate convergence resulted in local thrusting, rotation, translation, transtension, and extension along these structures, which led to exhumation of individual blocks at different times and rates from the late Eocene to the Pliocene [Hargraves and Shagam, 1969; Shagam et al., 1984; Kohn et al., 1984; Lugo and Mann, 1995].

[3] The structure of the Venezuelan Andes is controlled by a complex system of strike-slip and thrusts faults. Several tectonic models for the evolution of the Venezuelan Andes have been proposed based on geochronology, field observations, and seismic data [e.g., Kellogg and Bonini, 1982; Colletta et al., 1997; Audemard and Audemard, 2002]. However, because of the complex interaction of oblique plate motion involving several microplates with preexisting faults, as well as the absence of deep crustal seismic data, the fault structures and kinematics remain controversial.

[4] The purpose of this paper is to provide new constraints on the timing and rate of exhumation, and the topographic 


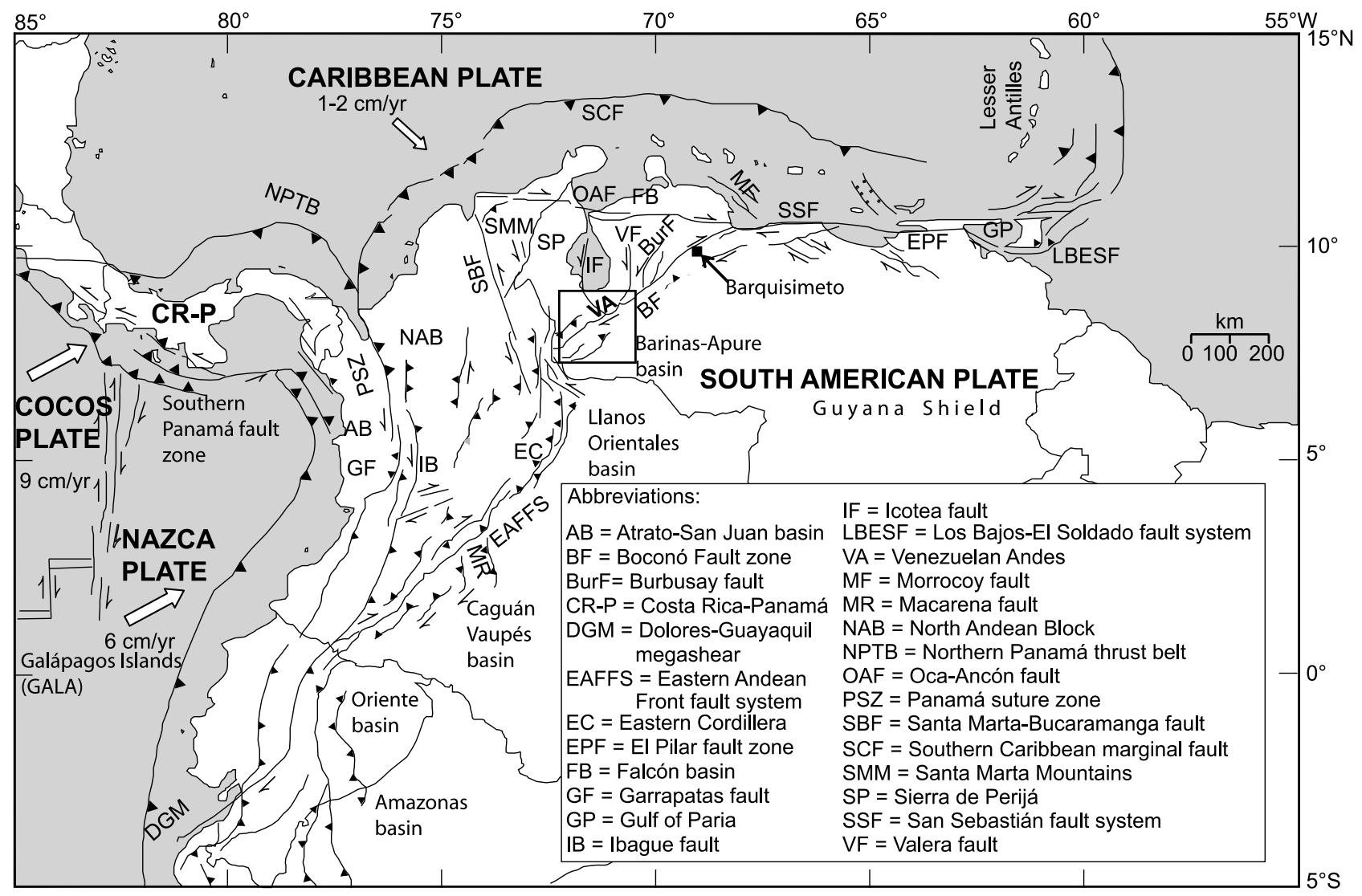

Figure 1. Major tectonic features of northern South America (modified from Colmenares and Zoback [2003]). Box shows extent of Figure 2.

evolution of individual tectonic blocks within the Venezuelan Andes, by using apatite fission track (AFT) thermochronology and Digital Elevation Model (DEM) analysis. AFT thermochronology expands on the existing data of Kohn et al. [1984] and M. Bermúdez et al. (Asynchronous Mio-Pliocene exhumation of the central Venezuelan Andes, submitted to Geology, 2010), by presenting 47 new AFT ages, as well as track length and kinetic data (Dpar and $\mathrm{Cl}$ measurements). We aim to constrain the evolution of the Venezuelan Andes within the Caribbean tectonic framework from the Miocene to the present, taking into account current tectonic models (Figure 3).

\section{Geodynamic Setting and Structure of the Venezuelan Andes}

[5] Current tectonic models for the Venezuelan Andes remain controversial with regard to the crustal structure, asymmetry and kinematics of the mountain belt. Several authors [Kellogg and Bonini, 1982; De Toni and Kellogg, 1993; Colletta et al., 1997] have proposed a thick-skinned deformation model, envisaging it as a doubly vergent orogenic wedge [Willett et al., 1993] resulting from incipient continental subduction of the Maracaibo block toward the southeast (Figure 3c). Others [Yoris and Ostos, 1997; Audemard and Audemard, 2002; Cediel et al., 2003] have applied an "orogenic float" model [e.g., Oldow et al., 1990] to the whole of the Caribbean-South American plate boundary zone, envisaging a major mid-crustal detachment underlying the Mérida Andes, Maracaibo basin and Perijá and Santa Marta ranges (Figures 3c and 3d) with either northwest- or southeast-directed subduction of the underlying lower crust. Although the seismic data are disputed [Audemard and Audemard, 2002], the most compelling evidence for southeast, instead of northwest-directed continental subduction is the formation of the $>6 \mathrm{~km}$ deep Maracaibo foreland basin to the northwest of the orogenic

Figure 2. Geologic and structural map of the Venezuelan Andes (modified from Audemard et al. [2000] and Hackley et al. [2005]) showing previously published and new samples used in this study. Different colors within single units pertain to different geological epochs [Hackley et al., 2005]. Numbers correspond to AFT ages. For detailed information on samples, see Tables 1 and 2. Inset shows major fault systems of the Venezuelan Andes and delimited tectonic blocks defined in this work (CATB, Cerro Azul Thrust; CB, Caparo; EB, Escalante; ECB, El Carmen; SLCB, Sierra La Culata; SNB, Sierra Nevada; and TB, Trujillo blocks). Carboniferous-Permian and Ordovician-Silurian were used to differentiate sedimentary of crystalline rocks. 


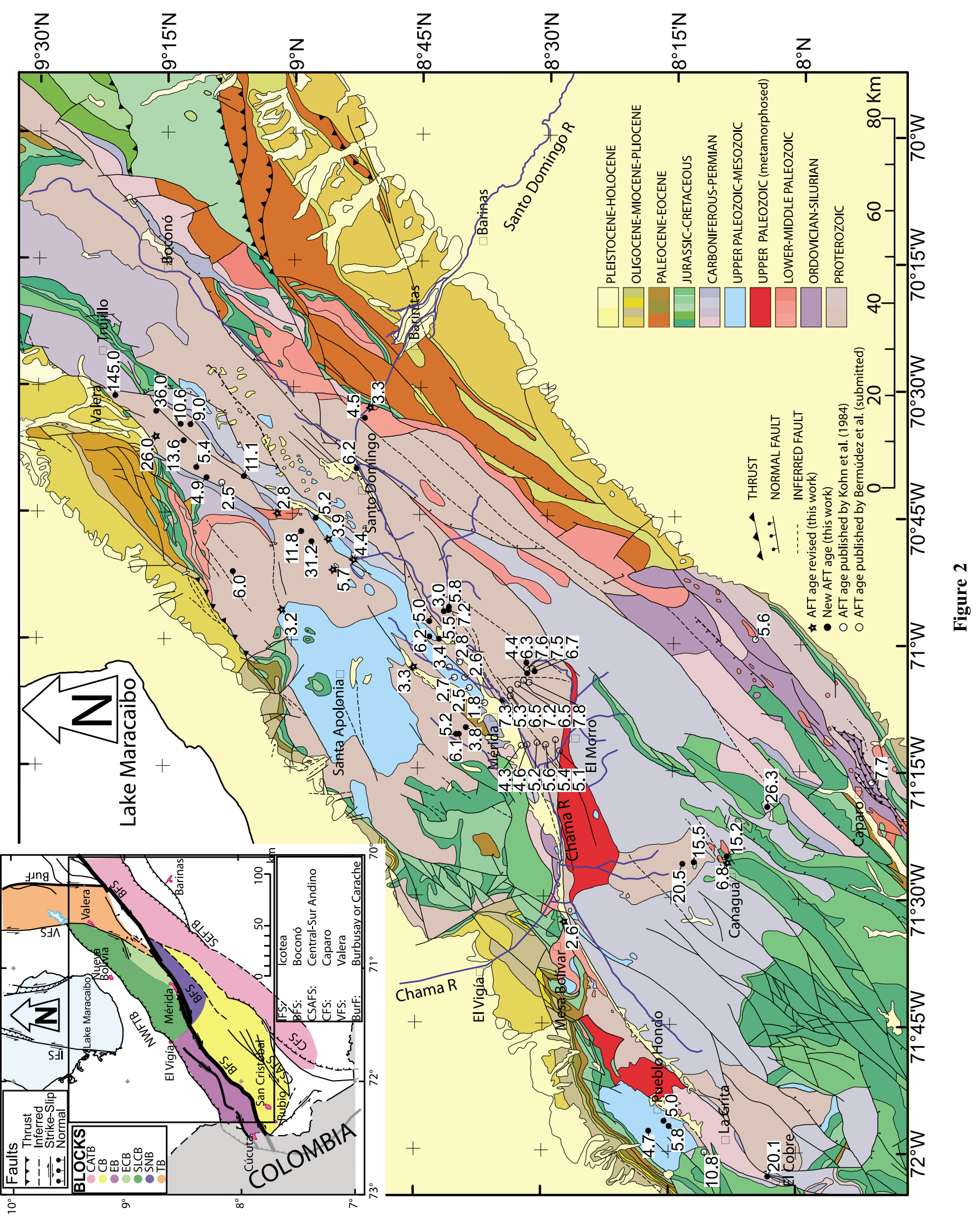



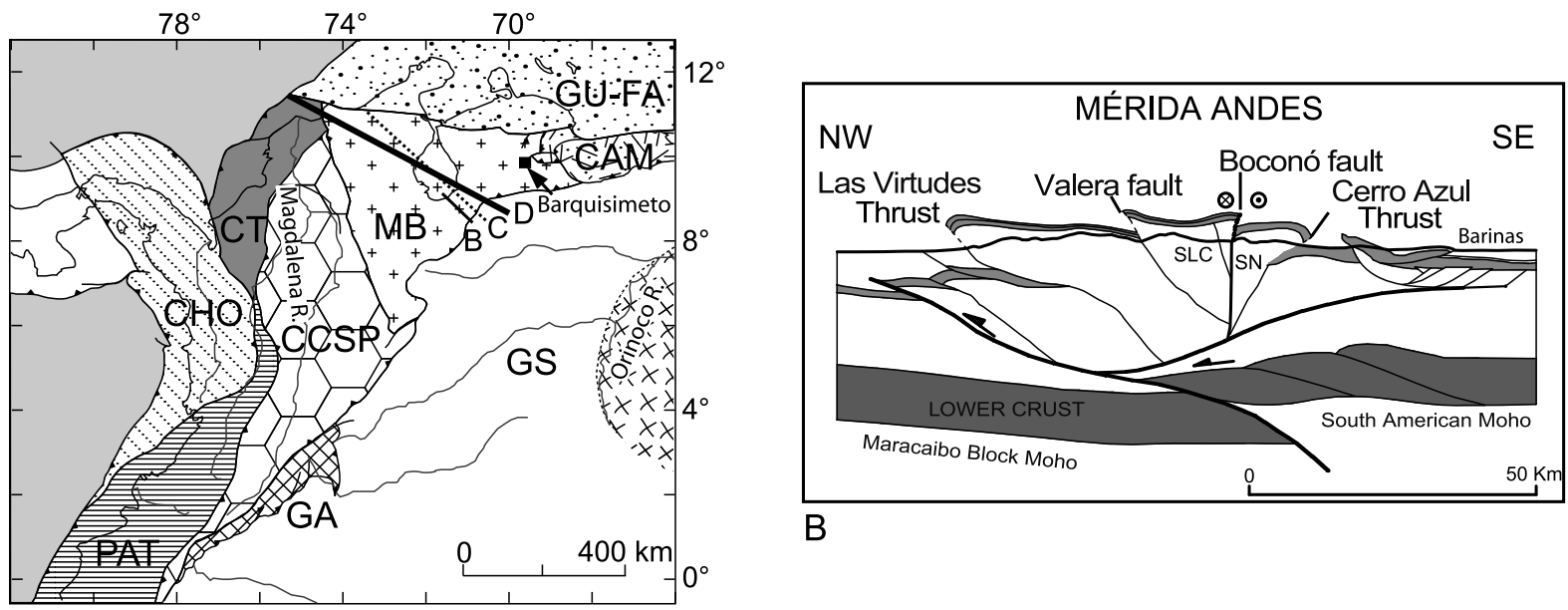

B

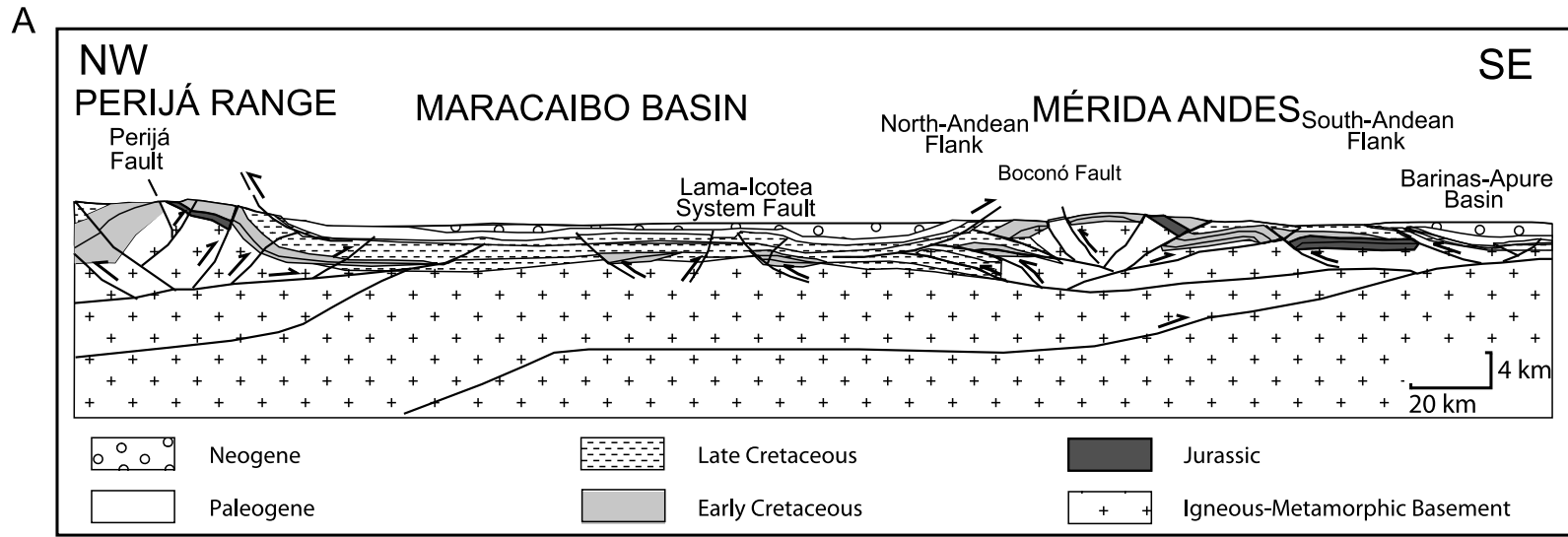

C

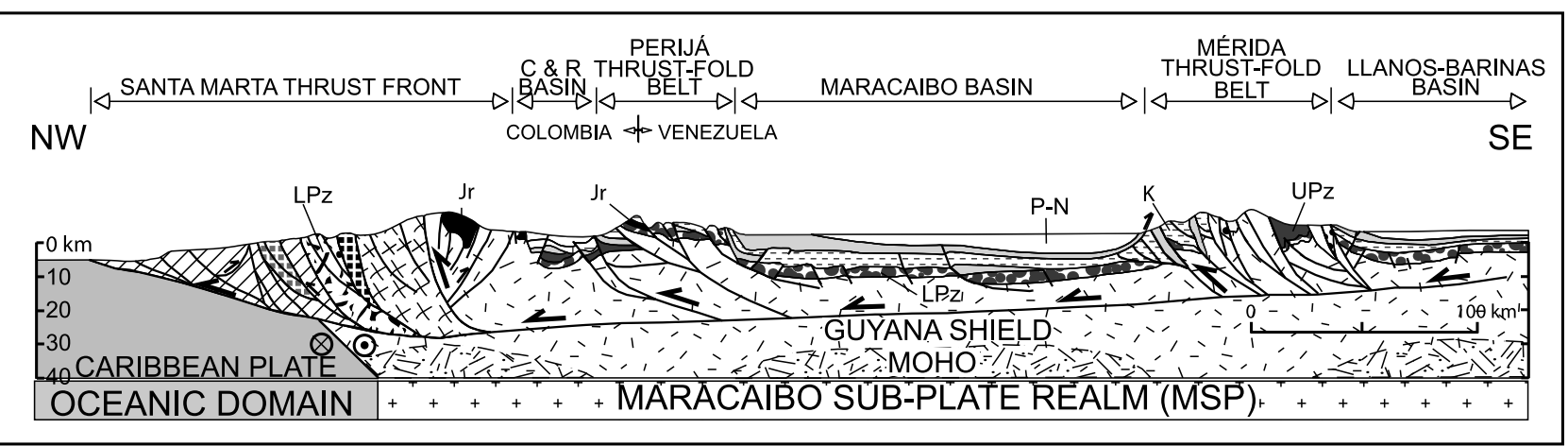

D

Figure 3. (a) Subdivision of northern Andes into tectonics domains: CAM, Caribbean Mountain terrane; CCSP, Central Continental Sub-Plate (Eastern Cordillera, Cordillera Real, San Lucas block, Ibague block); CHO, Chocó Arc; CT, Caribbean Terranes; GA, Garzón Massif; GS, Guyana Shield; GU-FA, GuajiraFalcón Composite Terrane; MB, Maracaibo block; PAT, Pacific assemblages [after Cediel et al., 2003]. (b-d) Different tectonic models presented as NW-SE structural cross sections across the Mérida Andes [Colletta et al., 1997] (SLC, Sierra la Culata block; SN, Sierra Nevada block) (Figure 3b); through the Maracaibo Basin from the Mérida Andes to the Perijá Range [Yoris and Ostos, 1997] (Figure 3c); and along the Maracaibo subplate [after Cediel et al., 2003] (Figure 3d). Abbreviations are C\&R basin, César and Ranchería basin; LPz, lower Paleozoic; UPz, upper Paleozoic; Jr, Jurassic; K, Cretaceous; P, Paleogene; N, Neogene. 
wedge (pro-side), compared to the relatively shallow $2 \mathrm{~km}$ deep retro-side Barinas basin, as shown by gravity and subsidence analyses [Chacín et al., 2005].

[6] The amount of shortening and the partitioning between shortening and strike-slip across the Venezuela Andes are also disputed. Shortening estimates across the belt range from 15 to $60 \mathrm{~km}$ [Colletta et al., 1997; Audemard and Audemard, 2002; Duerto et al., 2006]. The belt has absorbed significant lateral motion along major preexisting crustal faults, the foremost of which is the Boconó fault. Strike-slip deformation features, such as pop-up structures or releasing bend basins, are widespread [Schubert, 1980; 1982; Audemard and Audemard, 2002; Backé et al., 2006]. Estimates for the total right-lateral displacement on the Boconó fault system reach up to $80 \mathrm{~km}$ [Schubert, 1982], although more recent estimates are in the order of $30 \mathrm{~km}$ [Audemard and Audemard, 2002]. The present-day kinematics of the region, as shown by GPS analyses, are dominated by northeastward block escape of the Maracaibo block, driven by the ongoing motion of the Caribbean plate and northern Andean tectonics in Colombia [Kellogg and Vega, 1995; Weber et al., 2001; Pérez et al., 2001].

[7] The Venezuelan Andes are characterized by six major strike-slip fault systems (Figures 2 and 4), which are the right-lateral Boconó fault, Caparo fault and Central-Sur Andino fault system, and the left-lateral Icotea, Valera, and Carache or Burbusay faults systems. The orogen is delineated by two currently active foreland fold-and-thrust belts to the northwest and southeast, which incorporate PlioPleistocene sediments (Figures 1 and 2). The foremost of the strike-slip fault systems is the Boconó fault, which extends $\sim 500 \mathrm{~km}$ in a NE-SW direction along the entire Venezuelan Andes. The Boconó fault system is expressed at the surface by escarpments and aligned valleys and divides the Venezuelan Andes almost symmetrically in its central part (Mérida Andes). The Caparo fault is a dextral strike-slip system parallel to the Boconó fault in the southwestern part of Venezuelan Andes. The Central-Sur Andino fault is located between the Boconó and Caparo faults and does not show the same continuity as the other two fault systems (Figure 2), being subdivided into a southern and a northern part, without an apparent connection [Soulas, 1983]. The Burbusay and Valera faults are a system of continuous N-S trending faults that locally control the triangular Trujillo block in the northwest of the orogen (Figure 2). Running parallel to these, the Icotea fault bisects the Maracaibo block (MB in Figure 3a) and possibly converges with the Boconó fault close to the town of El Vigía (Figure 2). These fault systems separate distinct tectonic blocks [Colletta et al., 1997]. In this work we distinguish seven blocks (Figures 2 and $4 \mathrm{~b}$ ) based on their topographic signature and exhumation history. In the southwest, the Caparo block is truncated by the Boconó fault to the north, and the Caparo fault and Cerro Azul thrust block to the south. The Escalante block, to the north of the Caparo block, is limited to the north by the northwest foreland fold-and-thrust belt and to the south by the Boconó fault (Figures 2 and $4 \mathrm{~b}$ ). The Cerro Azul thrust block along the southeastern flank of the Venezuelan Andes is enclosed by the Boconó fault and the Central-Sur Andino fault to the north, and the SE fold-and- thrust belt to the south. In the central part of the Venezuelan Andes the Sierra Nevada block is bounded by the Boconó fault to the north and the Caparo block and Cerro Azul thrust to the south. The Sierra La Culata block is bordered by the NW fold-and-thrust belt to the north, the Boconó fault to the south and the Trujillo Block to the east. Within the Sierra La Culata block, the El Carmen block can be isolated. This block is restricted by two branches of the Boconó fault, the Mucujún and the Gavilán faults (Figures 2 and $4 \mathrm{~b}$ ). The Trujillo block at the northeastern end of the orogen is a triangular block defined by the Valera fault, Boconó fault, and the Burbusay fault.

\section{Methods and Analytical Procedures}

\subsection{Topographic Characteristics}

[8] Geological and topographic features of the Venezuelan Andes were characterized using a 90-m digital elevation model (DEM, Figure 4a), compiled from the Shuttle Radar Topography Mission (SRTM) data set. Topographic characteristics, such as mean elevation, mean hillslope angle and hypsometric parameters were calculated for individual tectonic blocks from the DEM using ArcMap ${ }^{\mathrm{TM}}$, Matlab ${ }^{\mathrm{TM}}$ and Splus $^{\mathrm{TM}}$ software. Slopes were calculated from directional derivatives between adjacent pixels, using the slope tool of ArcMap $^{\mathrm{TM}}$. Elevation and slope values were extracted from the DEM within the polygons that outline each individual block to quantify its topographic characteristics. All blocks are limited to the mountain belt proper as delimited by the northwest and southeast bounding thrust faults.

\subsection{Apatite Fission Track Thermochronology}

[9] Samples were collected in the Venezuelan Andes by Shagam in the 1980s and by Bermúdez, van der Beek and Bernet in 2007. Twenty AFT ages for the Venezuelan Andes were published by Kohn et al. [1984]. Ten of these samples were reanalyzed for this study using the external detector method and zeta calibration, compared to the population method and absolute neutron dose calculation used in the earlier analyses. Track length measurements were also performed on these samples. Where repeat determinations have been made, the new AFT ages are compared with those previously reported (Table 2). Recently, thirteen AFT ages were reported by Bermúdez et al. (submitted manuscript, 2010) for the Sierra Nevada block in the Mérida Andes (Table 1). To extend the existing AFT database, an additional 47 new AFT ages are presented in Table 2, which were dated at the fission track laboratories at Grenoble (11 samples) and Melbourne (26 new samples and 10 repeat samples from Kohn et al. [1984]). New sampling focused on regions that had not previously been targeted for AFT thermochronology. All sample locations used in this study are shown in Figure 2.

[10] Samples analyzed in Grenoble were separated from crushed rocks using standard magnetic and heavy liquid separation techniques. Apatite aliquots were mounted in epoxy, polished and etched for $20 \mathrm{~s}$ in $5.5 \mathrm{M} \mathrm{HNO}_{3}$ at $20^{\circ} \mathrm{C}$. Low- $U$ muscovite sheets were used as external detectors and these samples were irradiated at the well-thermalized 

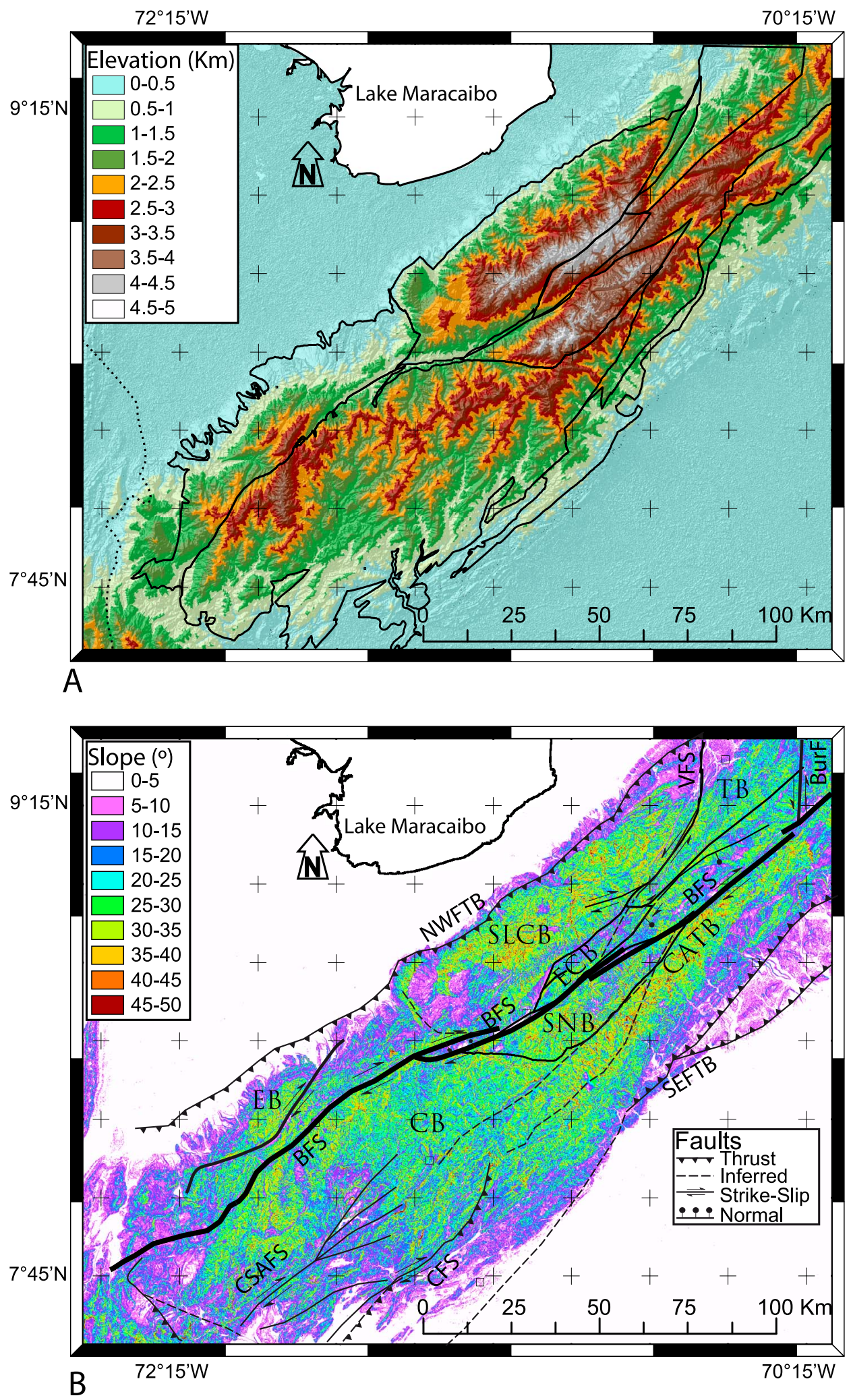

Figure 4. (a) Digital elevation model of the study area (data from NASA SRTM 90-m resolution topographic database). (b) Slope map of the Venezuelan Andes with tectonic blocks defined in this work (annotation as in Figure 3) and major fault systems (BFS, Boconó fault system; Burf, Burbusay fault; CFS, Caparo fault system; CSAFS, Central-Sur Andino fault system; NWFTB, northwestern fold-and-thrust belt; SEFTB, southeastern fold-and-thrust belt; VFS, Valera fault system). 


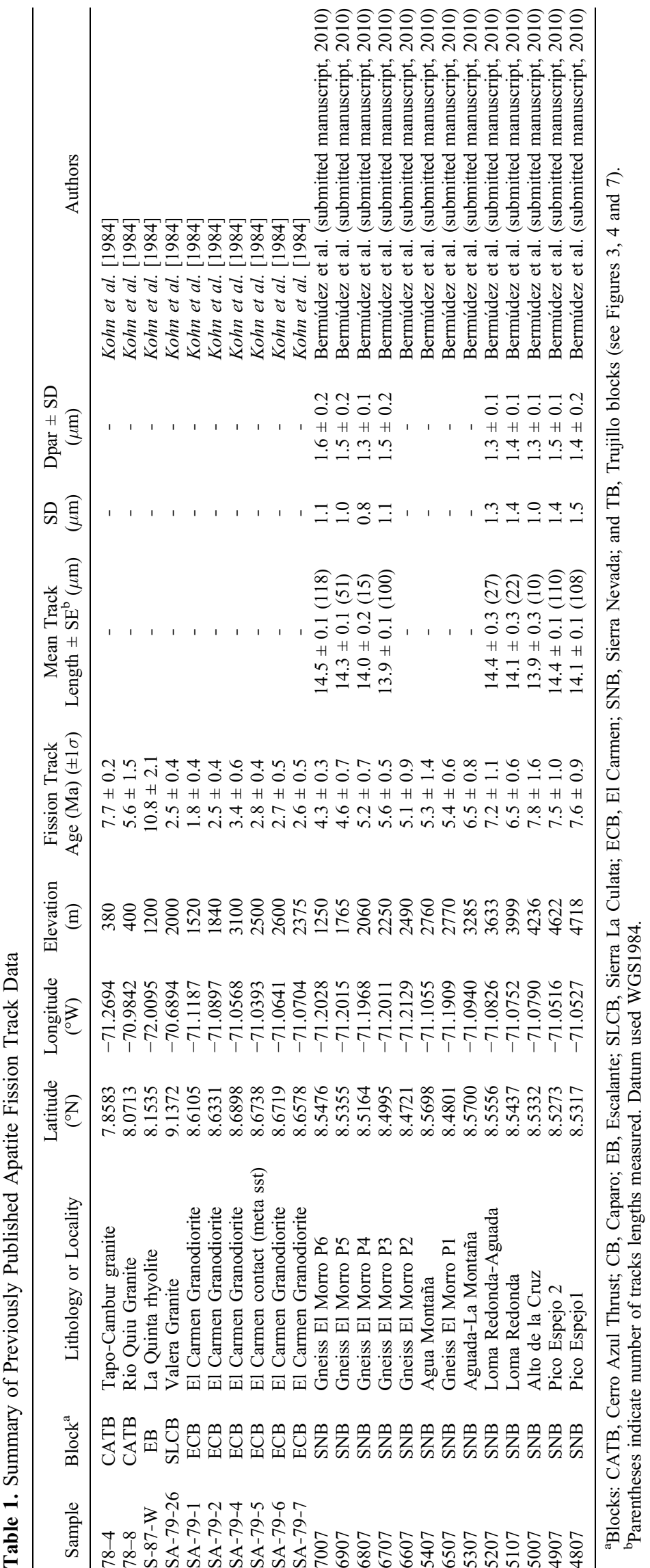




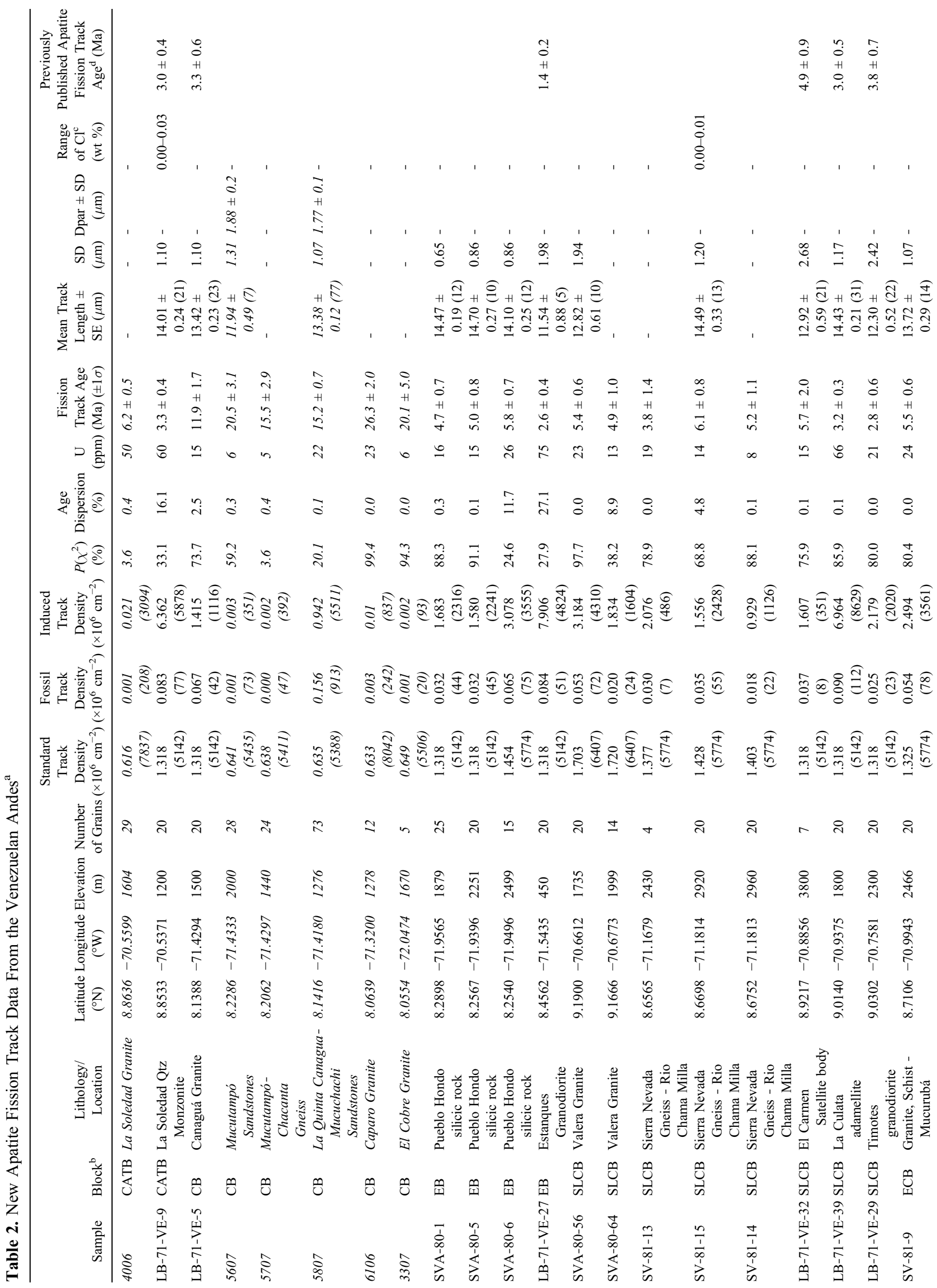




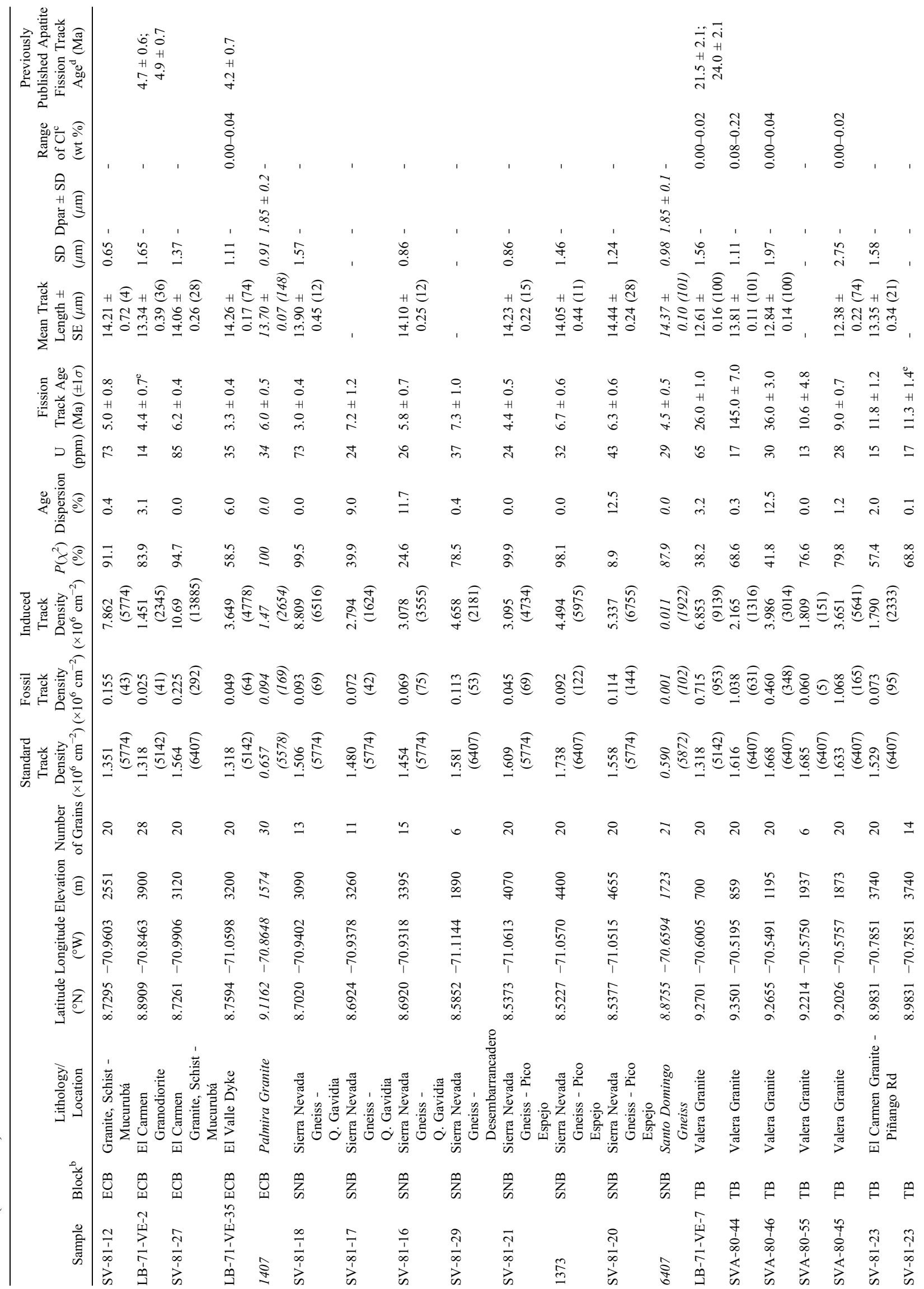




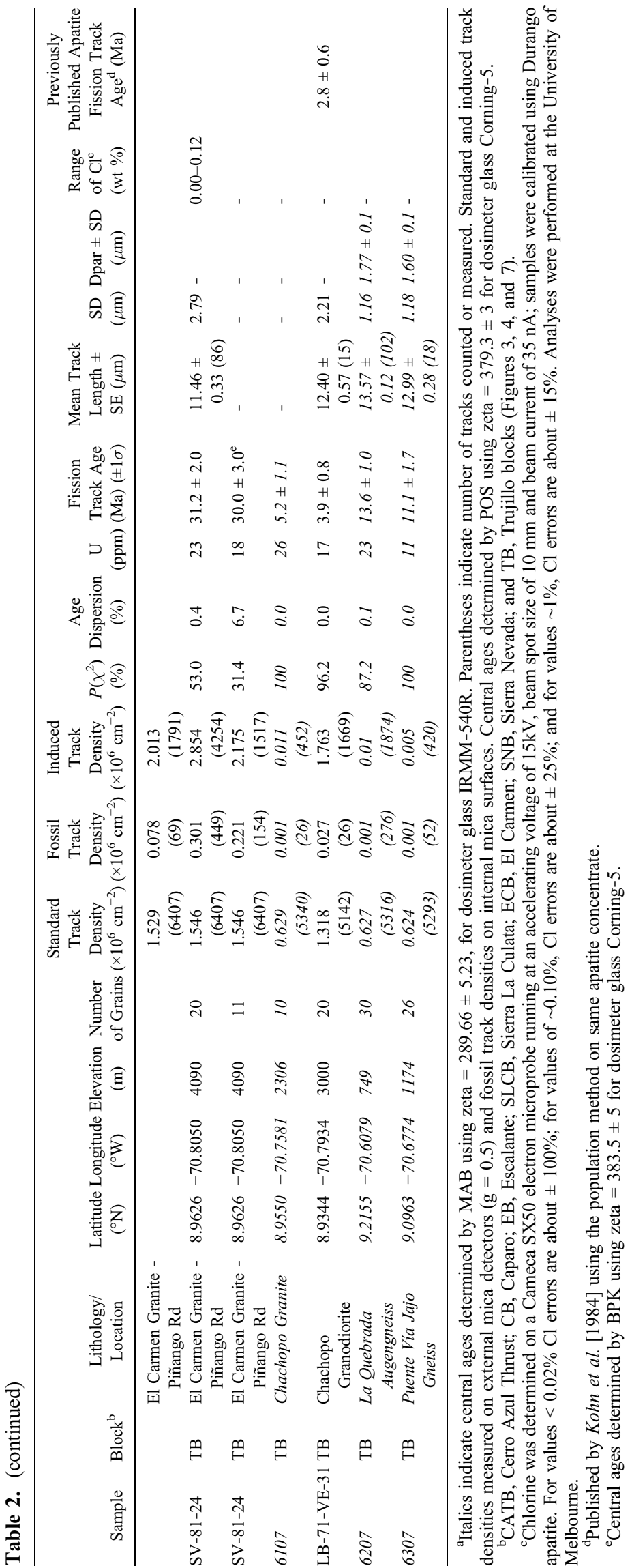


ORPHEE facility of the Centre d'Etudes Nucléaires in Gif-sur-Yvette, France, with a nominal fluence of $\sim 5 \times$ $10^{15}$ neutrons $/ \mathrm{cm}^{2}$. Neutron fluences were monitored using IRMM-540R dosimeter glasses. Mica detectors were etched in $48 \% \mathrm{HF}$ at $20^{\circ} \mathrm{C}$ for $18 \mathrm{~min}$. All grains were dated dry at $1250 \times$ magnification, using an Olympus $\mathrm{BH} 2$ microscope and the FTStage 4.04 system.

[11] Samples analyzed in Melbourne were mounted in epoxy resin on glass slides, ground and polished to an optical finish to expose internal grain surfaces. The mounts were etched in $5 \mathrm{M} \mathrm{HNO}_{3}$ for $20 \mathrm{~s}$ at room temperature to reveal fossil tracks. The external detector method was used for age determinations, with Brazil Ruby muscovite attached to the polished mounts to record induced tracks. Thermal neutron fluence was monitored by measuring the track density in muscovite plates attached to the Corning-5 (CN-5) standard glass. Neutron irradiations were carried out in the well-thermalized X-7 position of the Australian HIFAR Research Reactor at Lucas Heights, NSW, Australia. After irradiation, all muscovite detectors were etched for $27 \mathrm{~min}$ in $48 \% \mathrm{HF}$ at room temperature to reveal induced tracks. Track counting and horizontal confined track length measurements were performed on a Zeiss Axiotron microscope under transmitted light, using a dry $100 \times$ objective at a total magnification of $1250 \times$.

[12] Where possible, fission tracks in 20 suitable apatite grains were counted and 100 horizontal confined track lengths measured per sample (see Table 2). Fission track ages were calculated using the zeta-calibration method and standard fission track age equation [Hurford and Green, 1983]. The observed age spread is determined statistically using the chi-square test [Galbraith, 1981], which indicates the probability that all grains counted belong to a single population of ages. A chi-square probability of $<5 \%$ is evidence of an asymmetric spread of single grain ages and the "conventional analysis" [as defined by Green, 1981] based purely on Poissonian variation is not valid. All ages reported here are central ages [Galbraith and Laslett, 1993], essentially a weighted-mean age.

[13] Horizontal confined track lengths were measured in 43 samples. Aliquots of all these samples were irradiated using a ${ }^{252} \mathrm{Cf}$ source under vacuum for $140 \mathrm{~min}$ at the Thermochronology Laboratory at the University of Melbourne. Subsequently, these irradiated samples were etched under the same conditions as described above. Only fully etched and horizontal confined track lengths were measured in grains with polished surfaces parallel to prismatic crystal faces. Suitable track lengths were measured using a projection tube and a digitizing tablet, calibrated using a stage micrometer. For this procedure, the same magnification was applied as for track counting.

[14] The kinetics of AFT annealing are a function of chemical composition [Green et al., 1986; O'Sullivan and Parrish, 1995; Carlson et al., 1999] and mineralogical properties [Barbarand et al., 2003] of the analyzed apatite. Burtner et al. [1994] have shown that this may amount to a variation in total annealing temperature by as much as $\pm 20^{\circ} \mathrm{C}$. We take the possible kinetic variability in our samples into account by using the diameter of etched tracks at the surface of the apatite parallel to the crystallographic $c$-axis $\left(D_{\text {par }}\right)$ as a proxy for the annealing kinetics of the grains [Burtner et al., 1994]. $D_{\text {par }}$ of 100 tracks crossing the etched internal surface was measured using the same digitizing technique as used for measuring track lengths. The Dpar was measured only in the Grenoble fission track laboratory. For several samples analyzed at the University of Melbourne, apatite chlorine content was determined on grains also used for age determinations (Table 2$)$. The $\mathrm{Cl}$ determinations $([\mathrm{Cl}]<0.2 \mathrm{wt} \%)$ and $\mathrm{D}_{\text {par }}$ measurements $\left(\mathrm{D}_{\mathrm{par}}=1.6-1.9 \mu \mathrm{m}\right)$ both indicate that apatite composition is relatively homogeneous and close to fluorapatite [Carlson et al., 1999].

\subsection{Thermal History Modeling}

[15] AFT ages, track lengths and $D_{\text {par }}$ measurements of representative samples were used for determining timetemperature paths through inverse Monte Carlo modeling, using the HeFTy software of Ketcham [2005]. Version 1.6.7 of this software is based on the multikinetic annealing model of Ketcham et al. [2007b], with c-axis projected track length data [Ketcham et al., 2007a]. For modeling purposes each sample was constrained to a subsurface temperature between 140 and $160^{\circ} \mathrm{C}$ at a time somewhat older than the AFT age, and present-day surface temperature at the elevation where the sample was collected (typically $\sim 10-25^{\circ} \mathrm{C}$ ). The modeling strategy was to use a single large sampling space in order to allow models as much freedom as possible. As we expect these samples from an active orogen to reflect relatively simple cooling histories, cooling paths are defined as monotonic and composed of 16 random segments to allow for sufficient variability in the exhumation path. The $D_{\text {par }}$ kinetic parameter was used to calibrate annealing parameters as well as initial confined track lengths. Goodness of fit between modeled and measured track length distributions was assessed using the Kolmogorov-Smirnov test, with merit values of 0.5 and 0.05 for good and acceptable fits, respectively.

\section{Results}

\subsection{Topographic Characteristics}

[16] In order to highlight the topographic differences between individual tectonic blocks, we determined their mean elevations and mean hillslope angles; these data are summarized in Figures 4 and 5 and Table 3. The mean elevation of the Venezuelan Andes is about $2000 \mathrm{~m}$, with a standard deviation $(\sigma)$ of $855 \mathrm{~m}$ and a maximum elevation of $4981 \mathrm{~m}$ at Pico Bolívar in the Sierra Nevada block. The mean slope angle for the entire orogen is $21^{\circ}\left(\sigma=9^{\circ}\right)$. The Escalante, Cerro Azul, Trujillo and Caparo blocks exhibit lower values of mean elevation between 1160 and $1695 \mathrm{~m}$ (Figure 5c). These four blocks show positively skewed elevation distributions (Figure 5a and Table 3), implying relatively large areas at low elevations. The Escalante block is bisected by the San Pedro fault, parallel to the main trace of the Boconó fault system (Figure 2), which affects the distribution of relief by creating an anomalous distribution of low slopes. The influence of the San Pedro fault is evident in Figure 5b, in which the Escalante block curve shows a bimodal behavior because of lower slopes near the fault. 

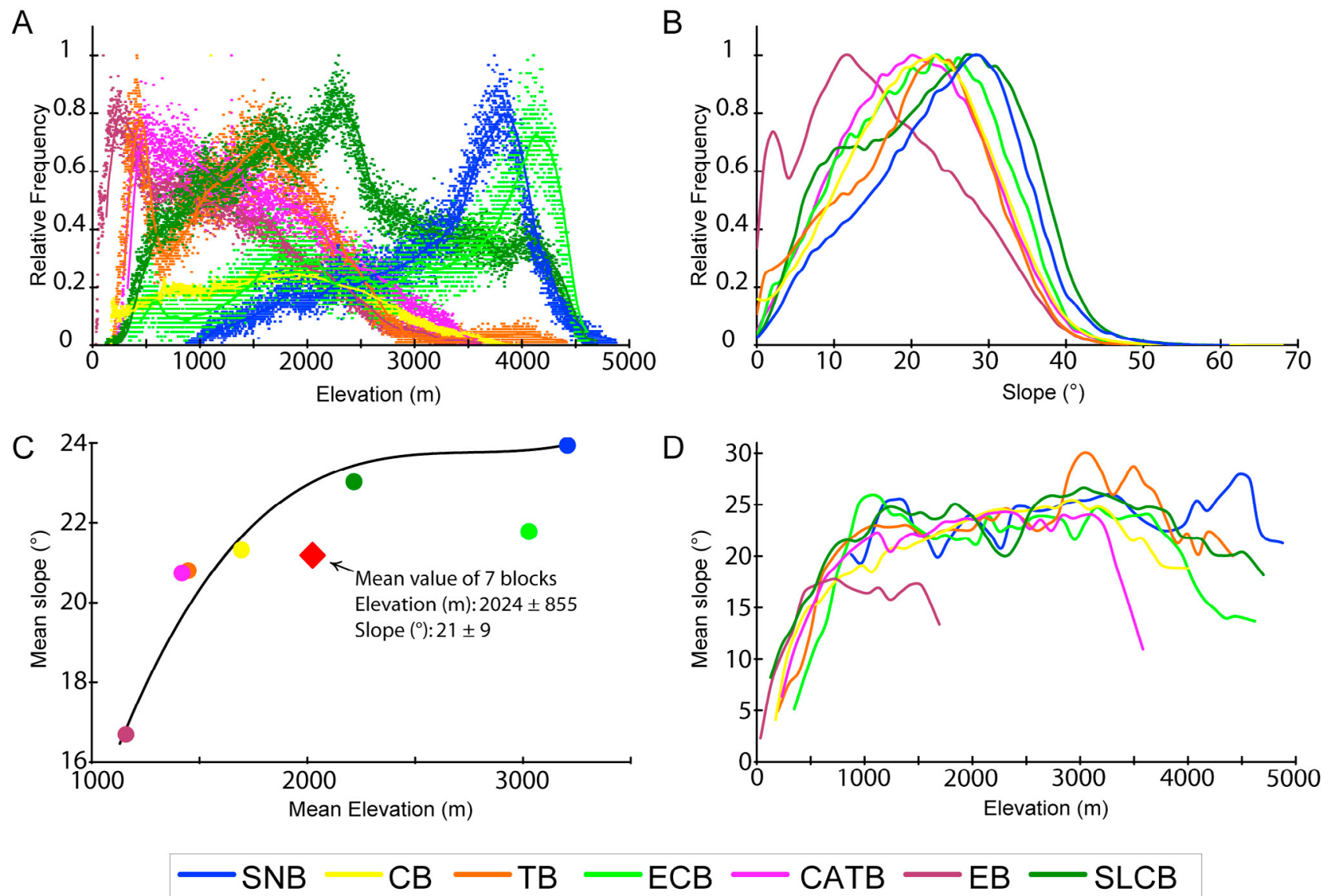

Figure 5. Hypsometric and geomorphic characteristics for the different tectonic blocks (annotation as in Figure 3). (a) Elevation distribution (dots, individual values; continuous line, 100-m bins). (b) Slope distribution. (c) Mean elevation versus mean slope for each block. (d) Altitudinal dependence of slopes for each block (100-m elevation bins). See text for discussion.

The highest topography is encountered in the Sierra La Culata, El Carmen and Sierra Nevada blocks, the latter two showing mean elevations of $\sim 3000-3200 \mathrm{~m}$, respectively. The hypsometric curve for the Sierra La Culata block is very wide and almost symmetric (weakly negative skewness of -0.1). The hypsometric curves for the El Carmen and Sierra Nevada blocks are negatively skewed, indicating widespread occurrence of high elevation areas. The slope distributions as a function of elevation (Figure 5d) of the Sierra La Culata and El Carmen blocks show a distinct minimum at elevations $>3800 \mathrm{~m}$, comparable to the slope distributions of the lower-elevation blocks, and indicative of low-relief landforms at high elevations. This minimum is conspicuously absent in the Sierra Nevada. Inspection of satellite imagery shows that the high-elevation low-relief surfaces in the Sierra La Culata are associated with ubiquitous glacial erosion features (cirque floors, glacially widened valley heads etc.); their occurrence close to the reconstructed equilibrium-line altitude for the Last Glacial Maximum in the Venezuelan Andes ( 3800 m [Stansell et al., 2007]), suggests that these features result from Pleistocene glaciation of the Mérida Andes [Schubert, 1974; Schubert

Table 3. Topographic Characteristics, Mean Elevation, and Mean Slope Angle for Different Tectonic Blocks in the Venezuelan Andes

\begin{tabular}{|c|c|c|c|c|c|c|c|c|}
\hline \multirow[b]{2}{*}{ Block } & \multicolumn{4}{|c|}{ Elevation $(\mathrm{m})$} & \multicolumn{4}{|c|}{ Slope (deg) } \\
\hline & Mean & $\mathrm{SD}$ & Mode & Skewness & Mean & SD & Mode & Skewness \\
\hline Caparo $(\mathrm{CB})$ & 1694 & 815 & 1098 & 0.7 & 21 & 9 & 23 & -0.2 \\
\hline Cerro Azul Thrust (CATB) & 1418 & 759 & 1291 & 0.2 & 21 & 9 & 20 & 0.1 \\
\hline El Carmen (ECB) & 3028 & 1066 & 4105 & -1.0 & 22 & 9 & 23 & -0.1 \\
\hline Escalante $(\mathrm{EB})$ & 1159 & 750 & 96 & 1.4 & 17 & 10 & 12 & 0.5 \\
\hline Sierra La Culata (SLCB) & 2216 & 1044 & 2289 & -0.1 & 23 & 10 & 28 & -0.5 \\
\hline Sierra Nevada (SNB) & 3207 & 802 & 3740 & -0.7 & 24 & 9 & 28 & -0.4 \\
\hline Trujillo (TB) & 1448 & 748 & 409 & 1.4 & 21 & 9 & 23 & -0.2 \\
\hline
\end{tabular}


and Clapperton, 1990]. Glacial erosion at high elevations will lead to rapid headward erosion and cirque retreat, leaving a large proportion of the surface area at an elevation range close to the ELA with relatively low relief [e.g., Mitchell and Montgomery, 2006; Egholm et al., 2009].

\subsection{Apatite Fission Track Data}

[17] All new AFT ages reported in this study are summarized in Table 2 and shown together with previously published AFT ages in Figures 2 and 6. Almost all samples passed the chi-square test at the $95 \%$ confidence interval. Results from independent analysts in the two labs are fully consistent, as shown for instance by overlapping ages for the Sierra Nevada, which were sampled along the same profile (Figure 2 and Table 2).

[18] The complete data set of 70 AFT ages for the Venezuelan Andes shows that different tectonic blocks have highly variable exhumation histories (Figures 2 and 6-8). The youngest AFT ages range between 1 and $3 \mathrm{Ma}$ and are found close to the Boconó fault, specifically in samples from the El Carmen block and at the limit between the Sierra La Culata and Escalante blocks. AFT ages between 4 and $8 \mathrm{Ma}$ are concentrated in the central part of the Venezuelan Andes, in the Sierra La Culata and Sierra Nevada blocks, and on both flanks of the chain in the Escalante block and the Cerro Azul thrust block. In the Caparo block, AFT ages range between 7 and $30 \mathrm{Ma}$ and are all substantially younger than the depositional ages of the Triassic-Jurassic La Quinta Formation [Hargraves and Shagam, 1969] from which they were collected. The Trujillo block is characterized by a wide range of AFT ages, increasing from $8 \mathrm{Ma}$ at its southeastern limit to $145 \mathrm{Ma}$ in the north. A strong correlation between AFT age and elevation is observed in the El Carmen and Sierra Nevada blocks, whereas this correlation is much weaker in the other blocks (Figure 7). However, part of this difference is due to the fact that the sampling strategy in the El Carmen and Sierra Nevada blocks was specifically aimed at obtaining an age-elevation profile [Kohn et al., 1984; Bermúdez et al., submitted manuscript, 2010], whereas this was not the case in the other blocks.

[19] After ${ }^{252} \mathrm{Cf}$ irradiation, we were able to obtain track length measurements from 34 new samples (Table 2), although only 10 samples provided a sufficient number ( $>50$ track length measurements; see below) for meaningful thermal history modeling. Bermúdez et al. (submitted manuscript, 2010) report 9 more sets of track length measurements, of which 5 are suitable for modeling (Table 2). Overall, the blocks with the youngest AFT ages (e.g., Sierra Nevada, Sierra La Culata, El Carmen) are characterized by relatively long mean track lengths (MTL) of $\sim 13$ to $14.5 \mu \mathrm{m}$ and narrow track length distributions (typically with standard deviations close to $1 \mu \mathrm{m})$. A plot of MTL versus AFT age (Figure 6, bottom) shows a clear peak (MTL $>14 \mu \mathrm{m}$ ) for ages of $5 \pm 1 \mathrm{Ma}$. Blocks characterized by older AFT ages (e.g., Trujillo and Caparo, Figure 7) have shorter and wider track length distributions: MTL ranges from 11.5 to $13.8 \mu \mathrm{m}$ and standard deviations are generally $>2 \mu \mathrm{m}$. A secondary peak of MTL $\approx 13.5 \mu \mathrm{m}$ occurs for ages of $\sim 13 \mathrm{Ma}$ in these blocks (Figure 7d). No track length data could be measured in samples from the Cerro Azul block.

\subsection{Thermal History Modeling}

[20] Modeling of cooling histories using HeFTy was performed on samples from the Sierra Nevada, Sierra La Culata, Caparo, and Trujillo blocks for which at least 50 confined track length measurements were available (Figure 8). Thermal histories for the Sierra Nevada block were determined for sample 4907 from 4600 m elevation at Pico Bolivar (Figure 8a) and sample 6407 from Santo Domingo, at $1700 \mathrm{~m}$ elevation $\sim 45 \mathrm{~km}$ to the northeast (Figure $8 b$ ). Both samples show a rapid, but diachronous phase of cooling (at rates of $\sim 70^{\circ} \mathrm{C} / \mathrm{Myr}$ ), from $\sim 7.5$ to $5 \mathrm{Ma}$ for sample 4907 and from $\sim 5$ to $3.5 \mathrm{Ma}$ for sample 6407 , slowing down since that time. Bermúdez et al. (submitted manuscript, 2010) used the 3D forward thermal-kinematic model Pecube [Braun, 2003; Braun et al., 2006] to model the AFT ages and MTL for the complete Sierra Nevada profile and showed that the observed diachronous cooling along the profile can be explained by a phase of rapid exhumation that commenced during middle-late Miocene time $(\sim 12-8 \mathrm{Ma})$ and slowed down in the Pliocene $(\sim 4 \mathrm{Ma})$. HeFTy modeling results of sample 6407 (Figure 8b) are similar to the HeFTy model of sample 5007 (Table 2) Bermúdez et al. (submitted manuscript, 2010) collected at a similar altitude along the El Morro profile of the Sierra Nevada block. Regardless of the $\sim 45 \mathrm{~km}$ horizontal distance between the two samples, their cooling histories are remarkably similar with rapid cooling of about $70^{\circ} \mathrm{C} / \mathrm{Myr}$ from 4.5 to $3.5 \mathrm{Ma}$ and much slower cooling afterwards.

[21] Sample 1407 (Figure 8c) from the Sierra La Culata block shows an initial phase of rapid cooling between $\sim 7$ and $\sim 5.5 \mathrm{Ma}$, at a rate of about $40^{\circ} \mathrm{C} / \mathrm{Myr}$, followed by a phase of slower cooling $\left(<10^{\circ} \mathrm{C} / \mathrm{Myr}\right)$ from $\sim 5.5 \mathrm{Ma}$ to the present. The cooling and exhumation history of this sample is very similar to those from the Sierra Nevada block.

[22] For the Caparo block, thermal modeling of sample 5807 is presented in Figure 8d and shows nearly linear cooling for this block since the early Miocene ( 22 Ma). The sample cooled through the AFT partial annealing zone (PAZ) at a rate of $\sim 7^{\circ} \mathrm{C} / \mathrm{Myr}$ between 19 and $10 \mathrm{Ma}$; but cooling rates have possibly slowed down somewhat since that time. The Trujillo block sample 6207 (Figure 8e) documents a clearer decrease in cooling rates, from $\sim 12^{\circ} \mathrm{C} / \mathrm{Myr}$ between 16 and $12 \mathrm{Ma}$ (middle Miocene) to $\sim 4^{\circ} \mathrm{C} / \mathrm{Myr}$ from the middle-late Miocene (12 Ma) to the present.

\section{Discussion}

\subsection{Data Synthesis}

[23] Our sampling for AFT thermochronology in the Venezuelan Andes focused on specific areas, in order to obtain age-elevation profiles or because of proximity to major faults, but partly also because of limited access to the terrain. Nonetheless, the current AFT age database permits mapping out the spatial distribution of AFT ages and track lengths, as shown in Figures 6 (top) and 6 (bottom), respec- 

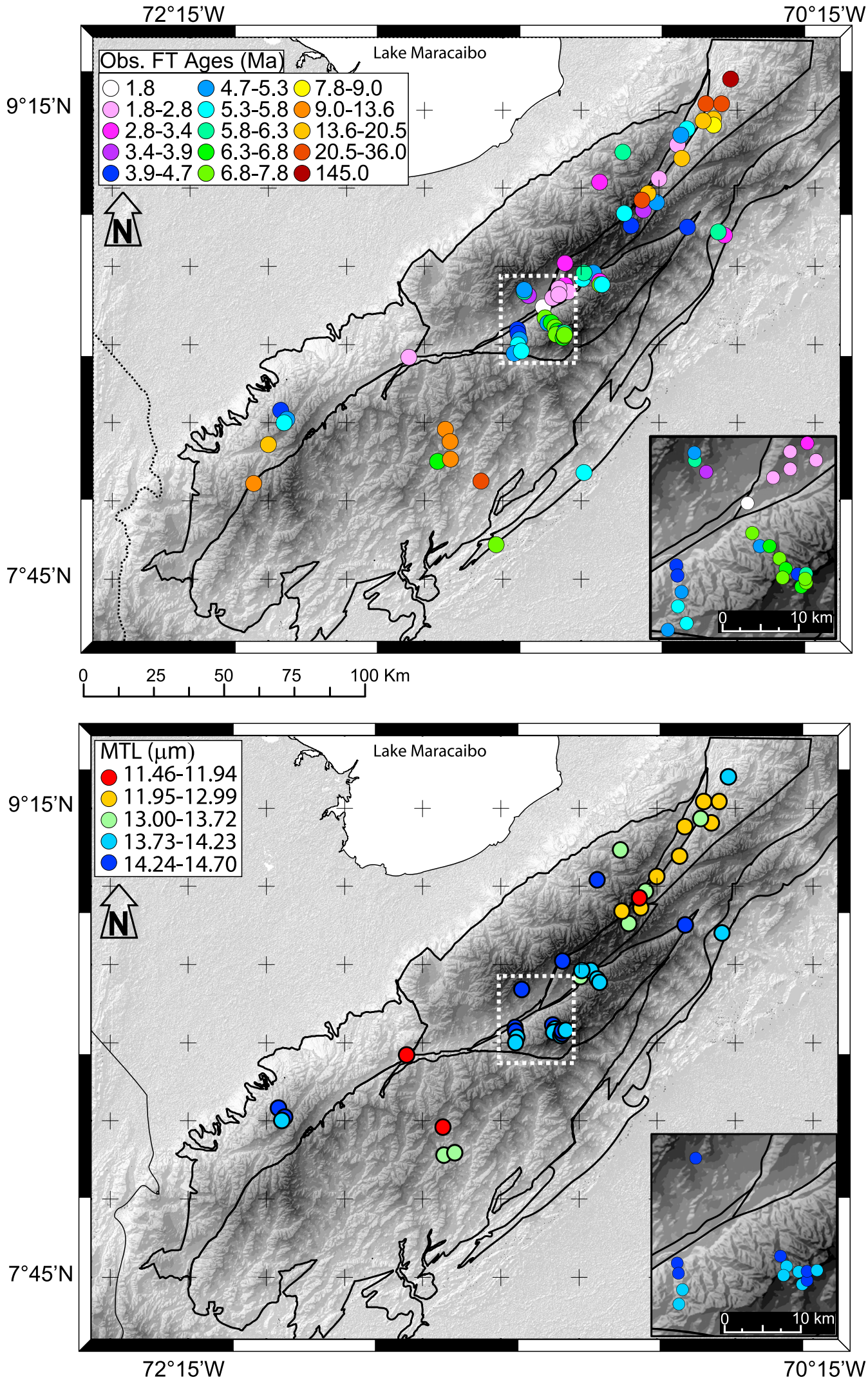

Figure 6. Shaded digital elevation model of the Venezuelan Andes with (top) AFT ages and (bottom) mean track lengths (MTL) for each block. Insets show zoom on Sierra Nevada de Mérida and El Carmen/ Sierra la Culata in the center of the belt. 

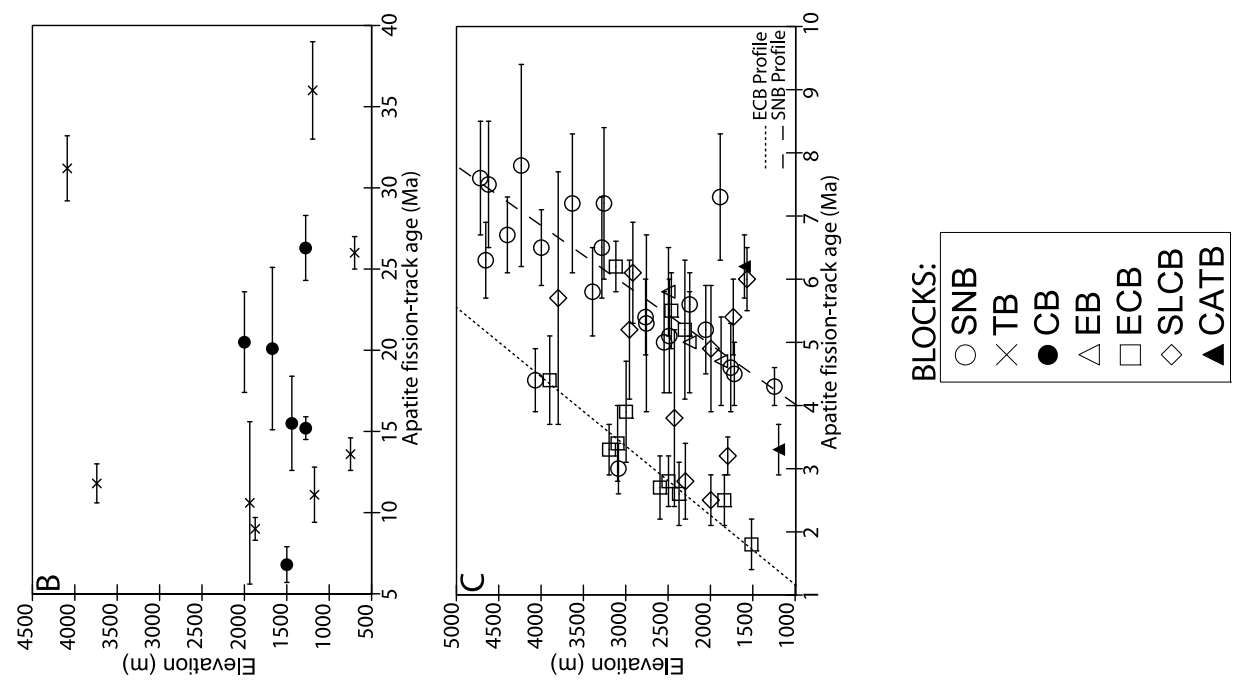

.⿱艹̈日్
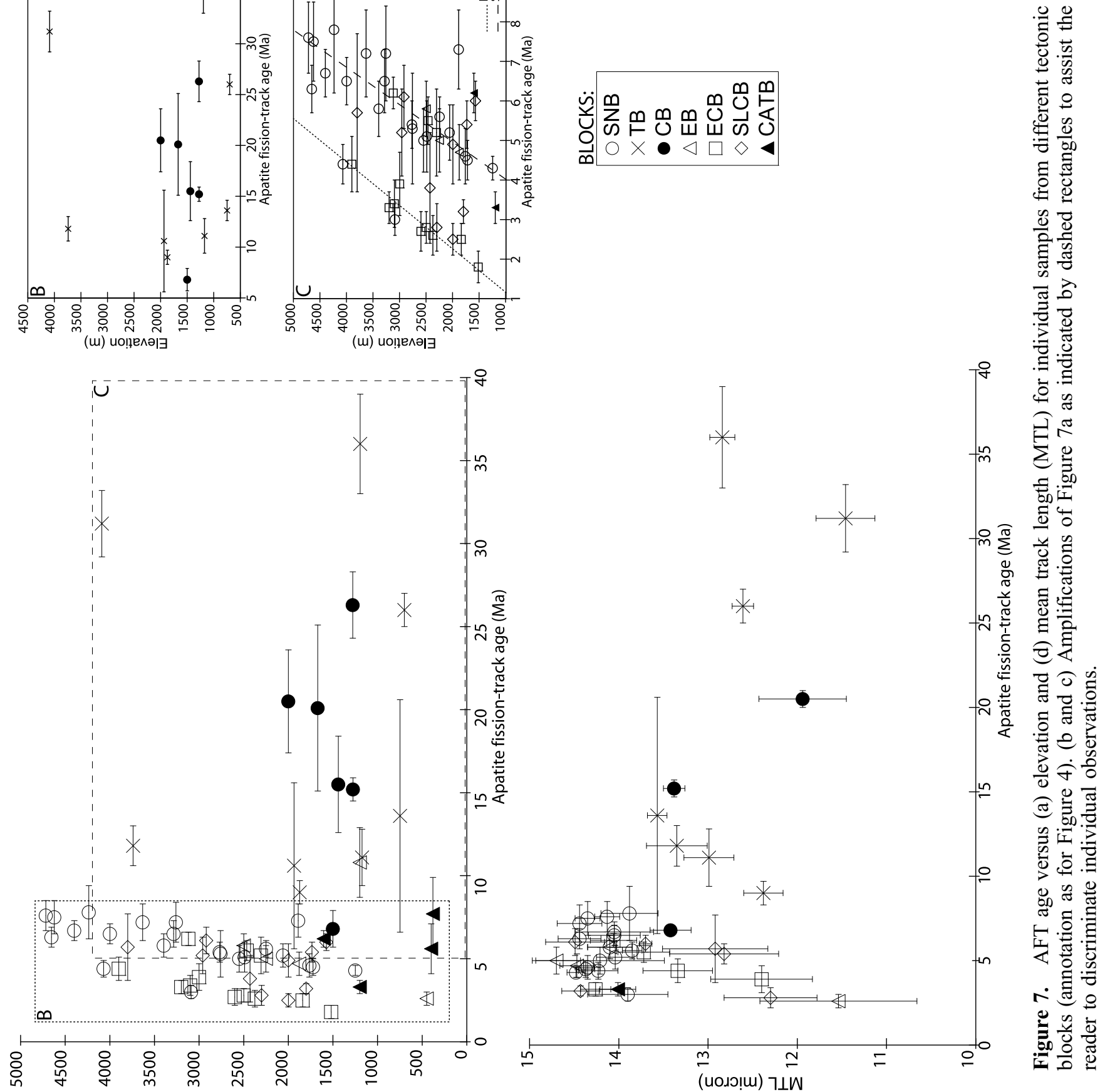

(w) ио!̣еләㅋ

$\ll$
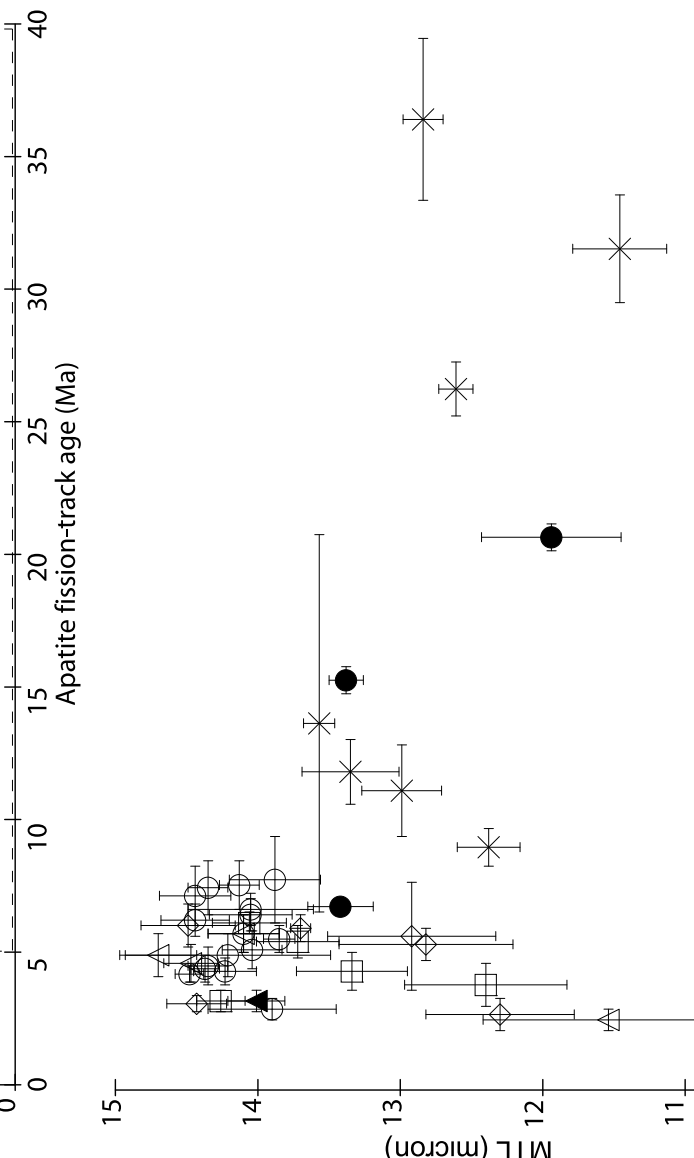

$\stackrel{n}{-}$
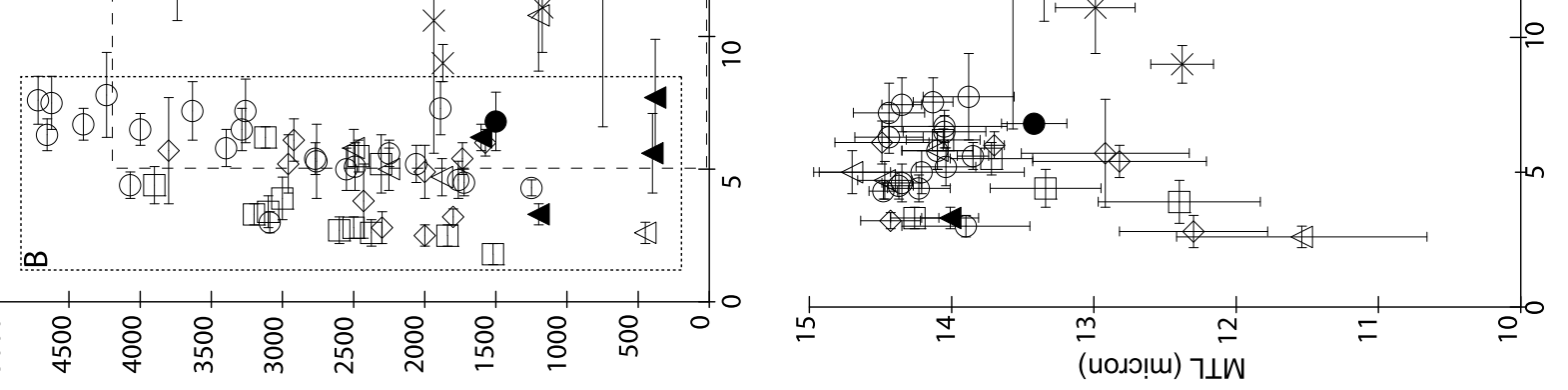

is

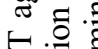

安 $\therefore$ 过 产竞离

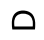



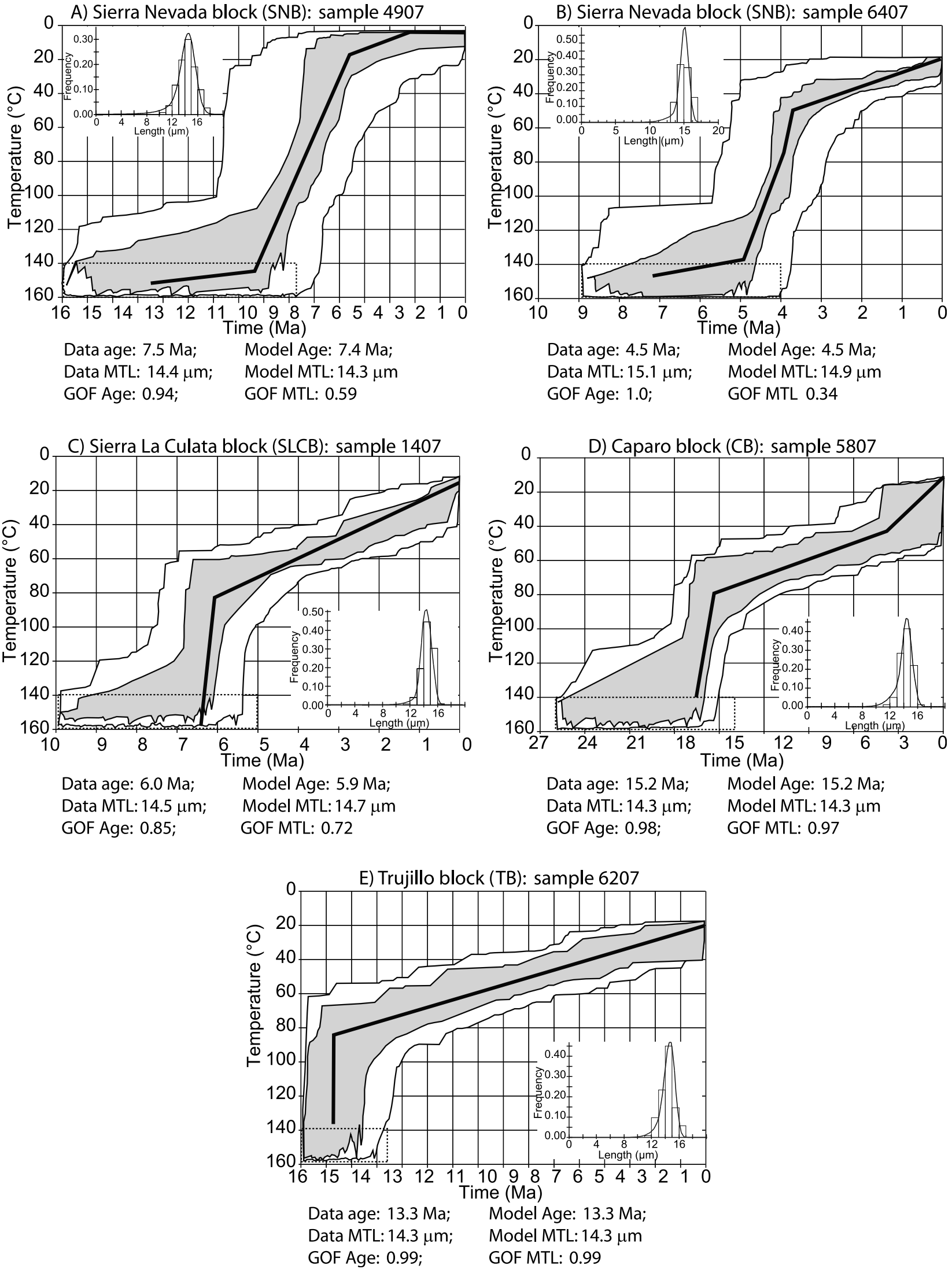

Figure 8

16 of 21 
tively. A spatial pattern emerges, with most of the youngest AFT ages and longest MTL in the Venezuelan Andes located in the central part of the range, close to the Boconó fault system (Figure 6).

[24] AFT ages and track length distributions in the Sierra Nevada, Sierra La Culata and El Carmen blocks (Figure 7) are compatible with rapid cooling through the apatite PAZ, followed by residence at shallower depths. Blocks cooled through the PAZ at different times: middle-late Miocene for the Sierra Nevada block, Pliocene for the El Carmen and Sierra La Culata blocks. AFT ages and track length distributions for the Escalante block, although insufficient for thermal history modeling, suggest a cooling history similar to the Sierra La Culata block. The Boconó fault, a rightlateral strike-slip fault that also displays vertical offset [Schubert, 1982; Giegengack, 1984], thus appears to have played a fundamental role in delimiting blocks with contrasting exhumation histories (see also Bermúdez et al. (submitted manuscript, 2010). During the late Miocene to early Pliocene, oblique convergence between the Maracaibo block and the South American plate was enhanced by collision of the Panamá arc with South America [Pindell and Kennan, 2001; Montes et al., 2005]. The oblique movement of individual tectonic blocks in the Venezuelan Andes along the Boconó fault system, during phases of transpression, appears to have controlled the timing of rapid exhumation by creating topography. Exhumation itself was driven by erosion of the newly created topography through river incision, with trunk rivers following the trend of the Boconó fault (e.g., Chama River, Santo Domingo River, Figure 2). As shown in Figure 5, the El Carmen and Sierra Nevada blocks currently host the highest topography, with mean elevations over 3000 and $3200 \mathrm{~m}$ respectively, and the largest number of peaks over $4000 \mathrm{~m}$ elevation in the Venezuelan Andes. The Sierra La Culata block as a whole has a mean elevation of about $2216 \mathrm{~m}$, but also contains several peaks over $4000 \mathrm{~m}$ (Figures $5 \mathrm{c}$ and $5 \mathrm{~d}$ ). The few available AFT cooling ages for this block are similar to those of the Sierra Nevada block, suggesting a similar exhumation history (Figures 6 and 7).

[25] Contrasting with the relatively young AFT ages in the central part of the Venezuelan Andes, middle Miocene and older AFT cooling ages are found in other areas of this mountain belt (Figures 6 and 7). Samples in the Caparo block yield ages ranging from 12 to $26 \mathrm{Ma}$ (samples LB-71VE-5 and 6106 respectively), with MTL varying from 11.5 to $13 \mu \mathrm{m}$, indicating comparatively slow cooling through the AFT PAZ at 15-20 Ma (Figure 7b; sample 5807 in Figure 8d). Therefore, this block experienced relatively slow cooling well before rapid exhumation started in the Sierra Nevada, Sierra La Culata, and El Carmen blocks. The topography of the Caparo block is more subdued (Figure 5d), with many peaks around $2000 \mathrm{~m}$ elevation. Nonetheless, slopes remain fairly steep $\left(20-25^{\circ} \mathrm{C}\right)$ for the highest elevations (Figures $5 \mathrm{~b}$ and $5 \mathrm{~d}$ ), as determined by DEM analysis.

[26] AFT ages of $>30 \mathrm{Ma}$ are restricted to the Trujillo block (Figures 6 and 7); the oldest AFT age encountered in this study (sample SVA-80-44; $145 \pm 7 \mathrm{Ma}$ ) is from the Valera Granite, located in the north of this block and away from major strike-slip faults. The MTL of this sample is $13.8 \pm 0.1 \mu \mathrm{m}$, which suggests relatively fast cooling through the apatite PAZ during the Late Jurassic-Early Cretaceous, with little subsequent exhumation. Mesozoic denudation of parts of the Andean basement is consistent with the widespread deposition of Jurassic-Cretaceous sandstones, which are mainly preserved in the southwest of the belt (Escalante and Caparo blocks). While the northern part of the Trujillo block appears to record an older, preorogenic cooling history, younger AFT ages are observed in the southwest of the block (Figure 6). The average MTL for the southwestern Trujillo block samples is $13.2 \pm 0.3 \mu \mathrm{m}$. The modeled cooling path of sample 6207 in the southwestern Trujillo block (Figure 8e) suggests cooling through the PAZ at a rate of about $14^{\circ} \mathrm{C} / \mathrm{Myr}$ during the middle Miocene, and slower cooling from the late Miocene to the present. Clearly, the Trujillo block was not affected by the rapid exhumation observed in the central Mérida Andes.

\subsection{Tectonic Implications}

[27] The structure and development of the Venezuelan Andes have been controlled by the reactivation of preexisting faults and structures (Figure 9), and the inversion of Jurassic rift grabens [Kellogg and Bonini, 1982; Colletta et al., 1997; Audemard and Audemard, 2002; Jacques, 2004], as it is also the case for the Eastern Cordillera in Colombia [Corredor 2003; Cortés et al., 2006; Mora et al., 2009; Parra et al., 2009]. These preexisting faults delimit tectonic blocks that are characterized by strongly variable exhumation histories, as observed in other transpressional mountain belts [e.g., Spotila et al., 2007].

[28] The signal of early (pre-Miocene) exhumation across the Venezuelan Andes is not very strong, because it is mostly overprinted by late Miocene to Pliocene exhumation. Only a few samples from the Valera and Caparo blocks record Paleogene (AFT ages of 26-36 Ma) or, in one case, Jurassic-Cretaceous (AFT age $145 \mathrm{Ma}$ ) exhumation. By contrast, existing zircon fission track (ZFT) data for the Venezuelan Andes [Kohn et al. 1984] are all late Mesozoic, ranging from $\sim 70$ to $\sim 160 \mathrm{Ma}$, indicating that Cenozoic tectonics did not involve sufficient exhumation to expose rocks with reset ZFT ages at the surface.

Figure 8. Time-temperature paths obtained from thermal-history modeling using HeFTy software [Ketcham, 2005] for representative samples of (a and b) Sierra Nevada, (c) Sierra La Culata, (d) Caparo, and (e) Trujillo blocks. The outer envelope contains acceptable fits; the inner, shaded envelope contains good fits (as defined by Ketcham [2005]); thick black line indicates best fit model: fit is indicated below the plot where measured and model results are compared (MTL, mean track length; SD, standard deviation; GOF, goodness of fit) and comparison of measured (histogram) and predicted (thin line) track length distribution is shown in the inset. Note that modeled $\mathrm{t}-\mathrm{T}$ paths are best constrained within the limits of the PAZ $\left(\sim 60-120^{\circ} \mathrm{C}\right)$. 

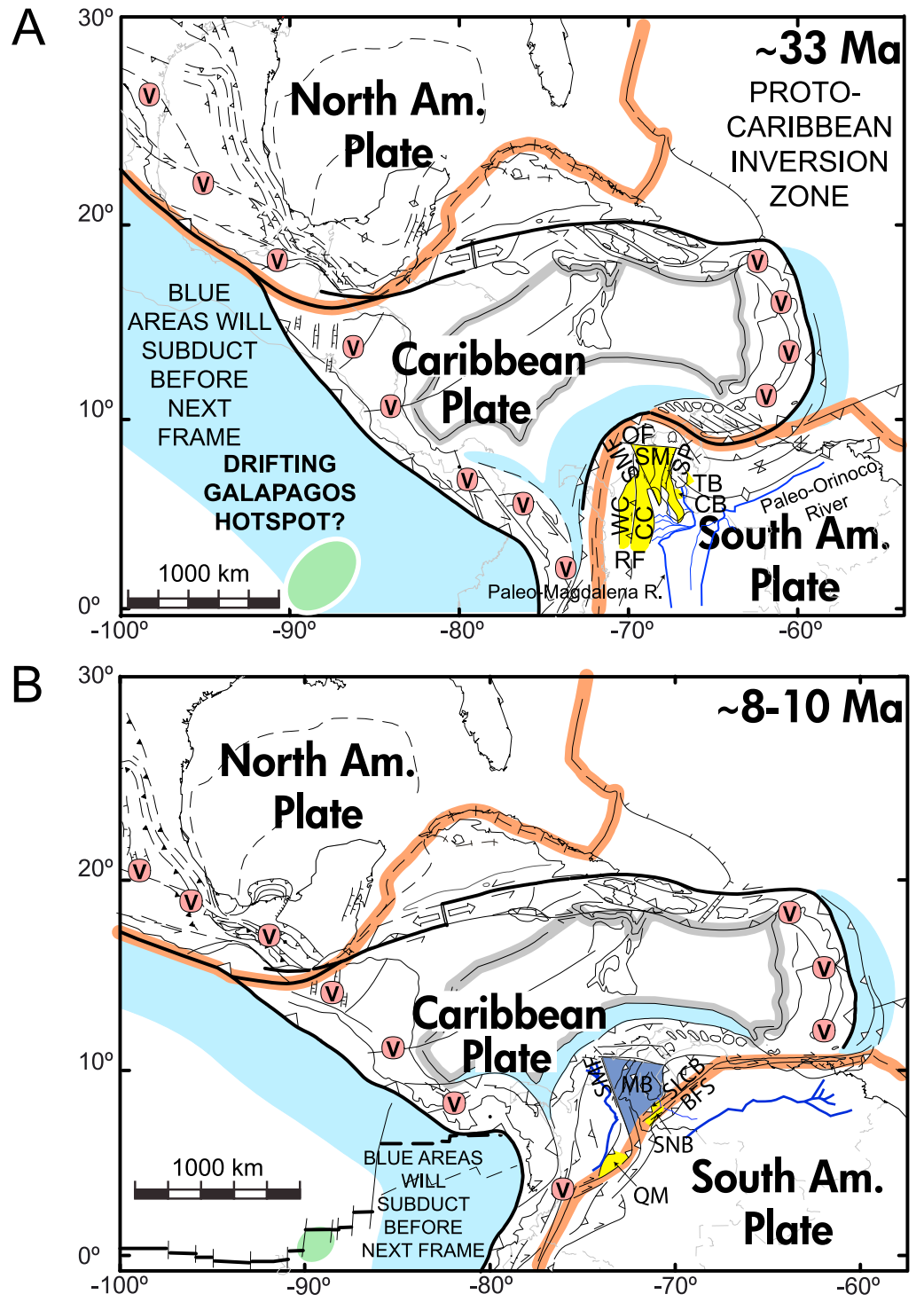

C

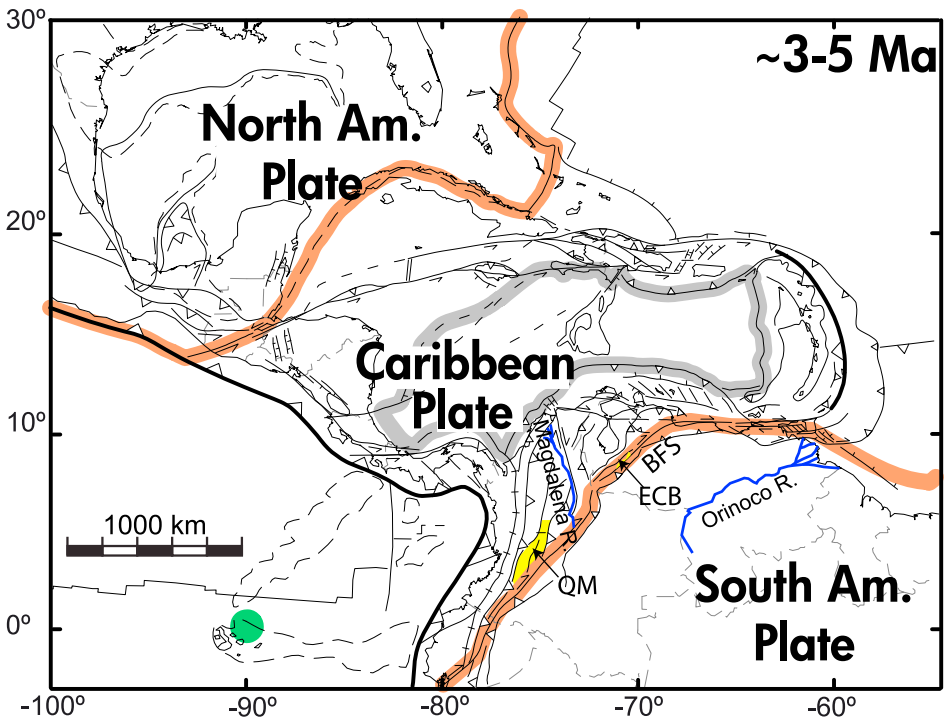

Figure 9 
[29] Distinct tectonic blocks in the Venezuelan Andes, limited by preexisting faults, responded in different ways to tectonic events that occurred in this zone, driven by the triple convergence of the South American, Caribbean and Farallon/Nazca plates (Figure 9). The similar early to middle Miocene exhumation history of the present-day Caparo and Trujillo blocks suggests that they were juxtaposed at that time, before being separated by right-lateral translation along the Boconó fault system [Schubert, 1982; Audemard and Audemard, 2002]. In effect, both blocks contain remnants of the inverted Jurassic Uribante graben [Lugo and Mann, 1995; Jacques, 2004] that continued into the Eastern Cordillera in Colombia. AFT ages from the Caparo and Trujillo blocks are similar to AFT ages obtained from Jurassic-Cretaceous sediments in the Eastern Cordillera [Parra et al., 2009] as well as to AFT ages from the Sierra de Perija in eastern Colombia [Shagam et al., 1984], suggesting a common exhumation history. Thus, inversion of the Uribante graben to form the present-day Eastern Cordillera of Colombia as well as the proto-Venezuelan Andes appears to have started during Oligocene times and to be associated with more widespread contractional deformation in northern South America, possibly associated with arrival of the buoyant Panama arc in the subduction zone at that time [Pindell and Kennan, 2001; Corredor, 2003].

[30] In the central part of the Venezuelan Andes and on both its flanks, the Escalante, El Carmen, Sierra La Culata, Sierra Nevada and Cerro Azul blocks record late MiocenePliocene exhumation resulting from transpression generated by clockwise rotation of the Maracaibo block (Figure 9b) and oblique convergence of this continental block with the stable South American plate during Miocene to present time [Colletta et al., 1997; Montes et al., 2005]. Block rotation, as supported by paleomagnetic analyses [Montes et al., 2005 and references therein], was driven by eastward movement of the Caribbean plate to the north of the Maracaibo block and collision of the Panamá arc with the northern Andes in Colombia. The Panamá arc collision commenced in the middle Miocene (15-12 Ma) but reached its climax between 8 and $3 \mathrm{Ma}$, resulting in the closure of the Panamá seaway during the Pliocene [Duque-Caro, 1990; Coates et al., 2004; Montes et al., 2005; Lunt et al., 2008]. The timing of these events is compatible with the late Miocene-Pliocene evolution of foreland basins on both the pro- and retro-side of the mountain belt [De Toni and Kellogg, 1993]. According to De Toni and Kellogg [1993], two sedimentary sequences of fluvial molasse deposits in the foreland basin to the northwest of the Venezuelan Andes are separated by a late Miocene discontinuity, at least in the southwestern part of the basin. The unconformity is possibly related to surface uplift as a consequence of the Panamá arc collision [Duque-Caro, 1990]. The onset of exhumation in the Sierra Nevada at $\geq 8 \mathrm{Ma}$ is also consistent with surface uplift and creation of significant topography around this time, as recorded by the late Miocene deflection of the tributaries of Orinoco and Magdalena rivers (Figure 9b) inferred from the Neogene sedimentary record [Hoorn et al., 1995; Díaz de Gamero, 1996].

[31] In the northeastern part of the Venezuelan Andes, the Trujillo Andes (Figures 2 and 4) are controlled by the interaction of the Boconó, Valera and Burbusay faults, which delimit the Trujillo block. Analysis of the AFT ages, cooling history and topography of the Trujillo block shows it does not record rapid exhumation during the late Miocene and Pliocene, hence the evolution of the Trujillo Andes is somewhat different from that of the Mérida Andes, The Trujillo Andes currently appears to be a site of active extension and tectonic escape [Backé et al., 2006], occurring as a result of the combination of oblique convergence between the South American plate and the Maracaibo block, with the presence to the north of the Caribbean plate considered as a free boundary. The oblique convergence and block rotation of the Maracaibo block thus leads to transpression and exhumation in the central part of the belt occurring simultaneously with extension and collapse to the northeast, consistent with the current stress field in the northern Andes as resolved from earthquake focal mechanisms [Colmenares and Zoback, 2003; Cortés and Angelier, 2005].

[32] The flanks of the central and southwestern Venezuelan Andes are bounded by NW and SE vergent foreland fold-and-thrust belts. The few available AFT ages from these areas are between 7.7 and 5.0 Ma (Figure 6). These thrusts accommodate most of the shortening across the Venezuelan Andes, as well as inversion of the Jurassic rift basins [Colletta et al., 1997; Duerto et al., 2006] and reactivation of preexisting faults. According to Duerto et al. [2006] the widespread Jurassic rifts suggest the possibility of thick-skinned reactivation of moderately to steeply dipping normal faults instead of low-angle thrusts as depicted

Figure 9. Possible kinematic configuration for the South American-Caribbean plate boundary zone during earliest Oligocene (Figure 9a), late Miocene (Figure 9b), and Pliocene times (Figure 9c). (a) Earliest Oligocene, widespread but relatively slow exhumation in the Venezuelan Andes (CB and TB), Western (WC), Central (CC), part of Eastern Cordillera (EC) and Santa Marta ranges (SM) of Colombia and Perijá (SP) range results from inversion of preexisting rift structures (possibly the OF, Oca Fault; SMF, Santa Marta Fault; and RF, Romeral Fault, were active) during regional compression, possibly related to initial subduction of Panama arc. (b) Late Miocene, rotation of the Maracaibo block (MB) is almost completed, and left-lateral strike-slip displacement between the Maracaibo block and the South American plate is concentrated on the BFS, producing translation and minor rotation in the Trujillo block (TB) during its tectonic escape. Major exhumation of the SNB and SLCB occurs during this phase. (c) Pliocene, final closure of Panama arc is expressed by rapid localized exhumation in parts of the Venezuelan Andes (ECB) and Eastern Cordillera (Quetame Massif (QM) [Parra et al., 2009]). See text for more detailed discussion (modified from Montes et al. [2005], Pindell and Kennan [2001], Corredor [2003], and Hoorn et al. [1995]). "V" in Figures 9a and 9b indicate associated volcanic rocks. Green point in Figures $9 \mathrm{a}, 9 \mathrm{~b}$, and $9 \mathrm{c}$ is the position of the Galápagos Island. 
in balanced cross sections [De Toni and Kellogg, 1993; Colletta et al., 1997]. A similar geometry has been proposed for the southern deformation front of the Cordillera Oriental in Colombia [Mora et al., 2009]. Both Colletta et al. [1997] and Duerto et al. [2006] argue for crustal-scale deformation in the Venezuelan Andes. In contrast, Yoris and Ostos [1997], Audemard and Audemard [2002] and Cediel et al. [2003] apply an orogenic-float model to the Venezuelan Andes, suggesting that the entire orogen is underlain by a mid-crustal detachment. Our data cannot clearly discriminate between these models: on the one hand, the strong control of major fault zones on the pattern of exhumation suggests that these are long-lived structures that may be rooted in the lower-crust or lithosphere; on the other hand, the absence of deeply exhumed rocks (as indicated by the lack of reset ZFT ages [Kohn et al., 1984]) appears more compatible with a shallow detachment underlying the mountain belt. Further analysis using the higher-temperature zircon fission track and/or (U-Th)/He systems may contribute to resolving the issue of the total amount of Cenozoic exhumation in the Venezuelan Andes. In parallel, unraveling the deep structure of the mountain belt requires seismic reflection and refraction surveying.

\section{Conclusions}

[33] AFT thermochronology and topographic analysis document the uplift and exhumation history of individual tectonic blocks in the Venezuelan Andes. Phases of rapid cooling and erosional exhumation as a consequence of tectonic surface uplift and development of high relief during the late Miocene and late Pliocene in the central part of the orogen contrast with older exhumation histories of the northeastern and southwestern parts of the Venezuelan Andes, where exhumation can be traced back to Oligocene times. Onset of exhumation in the Oligocene is consistent with records from the Eastern Cordillera and Sierra de Perija of Colombia. Exhumation in the central part of the Venezuelan Andes (Mérida Andes) and its flanks is the result of late Miocene to Pliocene transpression. Major surface uplift and exhumation occurred in the Sierra Nevada block since $\geq$ $8 \mathrm{Ma}$, in concordance with fluvial reorganization recorded by the sedimentary record during this period. A second phase of uplift and exhumation affected the El Carmen and Escalante blocks during the late Miocene-Pliocene, as also recorded by a major unconformity in the NW foreland basin succession. At the same time, the northeastern part of the mountain belt records extension and tectonic escape. The spatial and temporal patterns of exhumation in the Venezuelan Andes appear to be strongly controlled by preexisting faults delimiting major tectonic blocks, as is the case in many transpressional mountain belts elsewhere.

[34] Acknowledgments. This study was supported by the Consejo de Desarrollo Científico y Humanístico (CDCH-UCV) de la Universidad Central de Venezuela (UCV), Project PI 08-00-6219-2006, and ECOS Nord project V08U01. We thank the Instituto Nacional de Parques (INPARQUES) de la Región Andina and the Teléferico System, Mérida-Venezuela for permission to sample in the Sierra Nevada National Park and logistical support during fieldwork. We thank François Senebier for mineral separation. The University of Melbourne thermochronology laboratory receives infrastructure support under the AuScope Program of NCRIS. Neutron irradiation costs for samples analyzed were covered by the Australian Institute of Nuclear Science and Engineering (AINSE). This work is dedicated to the memory and career of Reginald Shagam, also known as "El Tigre De Los Andes", who died on 19 April 2008, in Beer Sheva, Israel. One of us (B.P.K.) in particular remembers him warmly as a colleague and friend, as an inspirational human being and as a geoscientist who made invaluable contributions to the understanding of Andean tectonics.

\section{References}

Aleman, A., and V. Ramos (2000), Northern Andes, in Tectonic Evolution of South America, 31st International Geological Congress, edited by U. G. Cordani et al., pp. 453-480, FINEP, Rio de Janeiro, Brazil.

Audemard, F. A., M. N. Machette, J. W. Cox, R. L. Dart, and K. M. Haller (2000), Map and database of Quaternary faults in Venezuela and its offshore regions, U.S Geol. Surv. Open File Rep., 00-018.

Audemard, F. E., and F. A. Audemard (2002), Structure of the Mérida Andes, Venezuela: Relations with the South America-Caribbean geodynamic interaction, Tectonophysics, 345, 299-327, doi:10.1016/ S0040-1951(01)00218-9.

Backé, G., D. Dhont, and Y. Hervouët (2006), Spatial and temporal relationships between compression, strike-slip and extension in the Central Venezuelan Andes: Clues for Plio-Quaternary tectonic escape, Tectonophysics, 425, 25-53, doi:10.1016/j.tecto.2006. 06.005 .

Barbarand, J., A. Carter, I. Wood, and A. Hurford (2003), Compositional and structural control of fission-track annealing in apatite, Chem. Geol., 198, 107-137, doi:10.1016/S0009-2541(02)00424-2.

Braun, J. (2003), Pecube: A new finite element code to solve the heat transport equation in three dimensions in the Earth's crust including the effects of a time-varying, finite amplitude surface topography, Comput. Geosci., 29, 787-794, doi:10.1016/ S0098-3004(03)00052-9.

Braun, J., P. van der Beek, and G. Batt (2006), Quantitative Thermochronology: Numerical Methods for the Interpretation of Thermochronological Data, 258 pp., Cambridge Univ. Press, Cambridge, U. K., doi:10.1017/CBO9780511616433

Burtner, R. L., A. Nigrini, and R. A. Donelick (1994), Thermochronology of lower Cretaceous source rocks in the Idaho-Wyoming thrust belt, $A A P G$ Bull., 78, 1613-1636.

Carlson, W. D., R. A. Ketcham, and R. A. Donelick (1999), Variability of apatite fission-track annealing kinetics: III. Extrapolation to geological time scales, Am. Mineral., 84, 1235-1255.

Case, J. E., R. Shagam, and R. F. Giegengack (1990), Geology of the northern Andes: An overview, in The Geology of North America, vol. H, The Caribbean Region, edited by G. Dengo and J. E. Case, pp. 177-200, Geol. Soc. of Am., Boulder, Colo.

Cediel, F., R. P. Shaw, and C. Cáceres (2003), Tectonic assembly of the Northern Andean Block, in The Circum-Gulf of Mexico and the Caribbean: Hydrocarbon Habitats, Basin Formation, and Plate Tectonics, edited by C. Bartolini et al., AAAPG Mem., 79, 815-848.

Chacín, L., M. I. Jácome, and C. Izarra (2005), Flexural and gravity modelling of the Mérida Andes and Barinas-Apure Basin, western Venezuela, Tectonophysics, 405, 155-167, doi:10.1016/j.tecto.2005.06.004

Coates, A. G., L. S. Collins, M. P. Aubry, and W. A. Berggren (2004), The geology of the Darien, Panama, and the late Miocene-Pliocene collision of the Panama arc with northwestern South America,
Geol. Soc. Am. Bull., 116, 1327-1344, doi:10.1130/ B25275.1.

Colletta, B., F. Roure, B. De Toni, D. Loureiro, H. Passalacqua, and Y. Gou (1997), Tectonic inheritance, crustal architecture, and contrasting structural styles in the Venezuelan Andes, Tectonics, 16, 777794, doi:10.1029/97TC01659.

Colmenares, L., and M. D. Zoback (2003), Stress field and seismotectonics of northern South America, Geology, 31, 721-724, doi:10.1130/G19409.1.

Corredor, F. (2003), Eastward extent of the Late EoceneEarly Oligocene onset of deformation across the northern Andes: Constraints from the northern portion of the Eastern Cordillera fold belt, Colombia, J. South Am. Earth Sci., 16, 445-457, doi:10.1016/ j.jsames.2003.06.002.

Cortés, M., and J. Angelier (2005), Current states of stress in the northern Andes as indicated by focal mechanisms of earthquakes, Tectonophysics, 403, 29-58, doi:10.1016/j.tecto.2005.03.020

Cortés, M., B. Colletta, and J. Angelier (2006), Structure and tectonics of the central segment of the Eastern Cordillera of Colombia, J. South Am. Earth Sci., 21, 437-465, doi:10.1016/j.jsames.2006.07.004.

De Toni, B., and J. Kellogg (1993), Seismic evidence for blind thrusting of the northwestern flank of the Venezuelan Andes, Tectonics, 12, 1393-1409, doi:10.1029/93TC01893.

Díaz de Gamero, M. L. (1996), The changing course of the Orinoco River during the Neogene: A review, 
Palaeogeogr. Palaeoclimatol. Palaeoecol., 123, 385-402, doi:10.1016/0031-0182(96)00115-0.

Duerto, L., A. Escalona, and P. Mann (2006), Deep structure of the Mérida Andes and Sierra de Perijá mountain fronts, Maracaibo Basin, Venezuela, AAPG Bull., 90, 505-528, doi:10.1306/ 10080505033 .

Duque-Caro, H. (1990), The Choco Block in the northwestern corner of South America: Structural, tectonostratigraphic, and paleogeographic implications, J. South Am. Earth Sci., 3, 71-84, doi:10.1016/ 0895-9811(90)90019-W.

Egholm, D. L., S. B. Nielsen, V. K. Pedersen, and J. E. Lesemann (2009), Glacial effects limiting mountain height, Nature, 460, 884-887, doi:10.1038/ nature 08263

Galbraith, R. F. (1981), On statistical models for fission track counts, Math. Geol., 13, 471-478, doi:10.1007/BF01034498.

Galbraith, R. F., and G. M. Laslett (1993), Statistical models for mixed fission track ages, Nucl. Tracks, 21, 459-470.

Giegengack, R. (1984), Late Cenozoic tectonic environments of the central Venezuelan Andes, Mem. Geol. Soc. Am., 162, 343-364.

Green, P. F. (1981), A new look at statistics in fission track dating, Nucl. Tracks, 5, 77-86, doi:10.1016/ 0191-278X(81)90029-9.

Green, P. F., I. R. Duddy, A. J. W. Gleadow, P. R. Tingate, and G. M. Laslett (1986), Thermal annealing of fission tracks in apatite: 1 . A qualitative description, Chem. Geol., 59, 237-253, doi:10.1016/ 0009-2541(86)90048-3.

Hackley, P. C., F. Urbani, A. W. Karlsen, and C. P. Garrity (2005), Geologic shaded relief map of Venezuela, U.S. Geol. Surv. Open File Rep. 2005-1038.

Hargraves, R. B., and R. Shagam (1969), Paleomagnetic study of La Quinta Formation, Venezuela, $A A P G$ Bull., 53, 537-552.

Hoorn, C., J. Guerrero, G. A. Sarmiento, and M. A Lorente (1995), Andean tectonics as a cause for changing drainage patterns in Miocene northern South America, Geology, 23, 237-240, doi: 10.1130/0091-7613(1995)023<0237: ATAACF $>2.3 . \mathrm{CO} ; 2$

Hurford, A. J., and P. F. Green (1983), The zeta calibration of fission track dating, Isot. Geosci., 1, 285317.

Jacques, J. M. (2004), The influence of intraplate structural accommodation zones on delineating petroleum provinces of the Sub-Andean foreland basins, Petrol. Geosci., 10, 1-19, doi:10.1144/ 1354-079303-582.

Kellogg, J. N., and W. E. Bonini (1982), Subduction of the Caribbean plate and basement uplifts in the overriding South American Plate, Tectonics, 1, 251-276, doi:10.1029/TC001i003p00251.

Kellogg, J., and V. Vega (1995), Tectonic development of Panama, Costa Rica, and the Colombian Andes: Constraints from global positioning system geodetic studies and gravity, Spec. Pap. Geol. Soc. Am., 295, 75-90.

Ketcham, R. A. (2005), Forward and inverse modeling of low-temperature thermochronology data, Rev. Mineral. Geochem., 58, 275-314, doi:10.2138/ rmg.2005.58.11.

Ketcham, R. A., A. Carter, R. A. Donelick, J. Barbarand, and A. J. Hurford (2007a), Improved measurement of fission-track annealing in apatite using $c$-axis projection, Am. Mineral., 92, 789-798, doi:10.2138/ am.2007.2280.

Ketcham, R. A., A. Carter, R. A. Donelick, J. Barbarand, and A. J. Hurford (2007b), Improved modeling of fission-track annealing in apatite, Am. Mineral., 92, 799-810, doi:10.2138/am.2007.2281.

Kohn, B., R. Shagam, P. Banks, and L. Burkley (1984), Mesozoic-Pleistocene fission track ages on rocks of the Venezuelan Andes and their tectonic implications, Mem. Geol. Soc. Am., 162, 365-384.

Lugo, J., and P. Mann (1995), Jurassic-Eocene tectonic evolution of Maracaibo basin, Venezuela, in Petroleum Basins of South America, A. J. Tankard, R. Suárez S., and H. J. Welsink, AAPG Mem., 62, 699-725.

Lunt, D. J., P. J. Valdes, A. Haywood, and I. C. Rutt (2008), Closure of the Panama Seaway during the Pliocene: Implications for climate and Northern Hemisphere glaciation, Clim. Dyn., 30, 1-18, doi:10.1007/s00382-007-0265-6.

Mitchell, S. G., and D. R. Montgomery (2006), Influence of a glacial buzzsaw on the height and morphology of the Cascade Range in central Washington State, USA, Quat. Res., 65, 96-107, doi:10.1016/j. yqres.2005.08.018

Montes, C., R. D. Hatcher, and P. Restrepo-Pace (2005), Tectonic reconstruction of the northern Andean blocks: Oblique convergence and rotations derived from the kinematics of the Piedras-Girardot area, Colombia, Tectonophysics, 399, 221-250, doi:10.1016/j.tecto.2004.12.024

Mora, A., T. Gaona, J. Kley, D. Montoya, M. Parra, L. I. Quiroz, G. Reyes, and M. R. Strecker (2009), The role of inherited extensional fault segmentation and linkage in contractional orogenesis: A reconstruction of Lower Cretaceous inverted rift basins in the Eastern Cordillera of Colombia, Basin Res., 21, 111-137, doi:10.1111/j.1365-2117.2008.00367.x.

Oldow, J. S., A. W. Bally, and H. G. Avé Lallemant (1990), Transpression, orogenic float, and lithospheric balance, Geology, 18, 991-994, doi:10.1130/00917613(1990)018<0991:TOFALB $>2.3 . \mathrm{CO} ; 2$.

O’Sullivan, P. B., and R. R. Parrish (1995), The importance of apatite composition and single-grain ages when interpreting fission track data from plutonic rocks: A case study from the Coast Ranges, British Colombia, Earth Planet. Sci. Lett., 132, 213-224, doi:10.1016/0012-821X(95)00058-K

Parra, M., A. Mora, E. R. Sobel, M. R. Strecker, and R. González (2009), Episodic orogenic front migration in the northern Andes: Constraints from lowtemperature thermochronology in the Eastern Cordillera, Colombia, Tectonics, 28, TC4004, doi: $10.1029 / 2008$ TC002423.

Pérez, O. J., R. Bilham, R. Bendick, J. R. Velandia, N. Hernández, C. Moncayo, M. Hoyer, and M. Kozuch (2001), Velocity field across the southern Caribbean plate boundary and estimates of Caribbean/South American plate motion using GPS geodesy 1994-2000 Geophys. Res. Lett., 28, 29872990, doi:10.1029/2001GL013183.

Pindell, J., and L. Kennan (2001), Kinematic evolution of the Gulf of Mexico and Caribbean, in Petroleum Systems of Deep-Water Basins: Global and Gulf of Mexico Experience: GCSSEPM Foundation, 21st Annual Research Conference, Transactions, edited by R. H. Fillon, N. C. Rosen, and P. Weimer, pp. 193-220, Gulf Coast Sect., Soc. for Sediment. Geol., Houston, Tex.

Schubert, C. (1974), Late Pleistocene Mérida Glaciation, Venezuelan Andes, Boreas, 3, 147-151.

Schubert, C. (1980), Late-Cenozoic pull-apart basins, Boconó fault zone, Venezuelan Andes, J. Struct. Geol., 2, 463-468, doi:10.1016/0191-8141(80) 90008-5.

Schubert, C. (1982), Neotectonics of Boconó fault, western Venezuela, Tectonophysics, 85, 205-220, doi:10.1016/0040-1951(82)90103-2.

Schubert, C., and C. M. Clapperton (1990), Quaternary glaciations in the northern Andes (Venezuela, Colombia and Ecuador), Quat. Sci. Rev., 9, 123 135, doi:10.1016/0277-3791(90)90014-2.

Shagam, R., B. P. Kohn, P. Banks, L. Dasch, R. Vargas, G. Rodríguez, and N. Pimentel (1984), Tectonic implications of Cretaceous-Pliocene fission track ages from rocks of the circum-Maracaibo Basin region of western Venezuela and eastern Colombia, Mem. Geol. Soc. Am., 162, 385-412.

Soulas, J. P. (1983), Tectónica cuaternaria de la mitad Sur de los Andes Venezolanos-Grandes Rasgos. Simposio de Neotectónica, Sismicidad y Riesgo Geológico en Venezuela y el Caribe (abstract), Acta Cient. Venez., 34, 525.

Spotila, J. A., M. A. House, N. A. Niemi, R. C. Brady, M. Oskin, and J. T. Buscher (2007), Patterns of bedrock uplift along the San Andreas fault and implications for mechanisms of transpression, in Exhumation Associated With Continental Strike-Slip Fault Systems, edited by A. B. Till et al., Spec. Pap. Geol. Soc. Am., 434, 15-33.

Stansell, N. D., P. J. Polissar, and M. B. Abbott (2007), Last glacial maximum equilibrium-line altitude and paleo-temperature reconstructions for the Cordiller de Mérida, Venezuelan Andes, Quat. Res., 67, 115127, doi:10.1016/j.yqres.2006.07.005.

Weber, J. C., T. H. Dixon, C. DeMets, W. B. Ambeh, P. Jansma, G. Mattioli, J. Saleh, G. Sella, R. Bilham, and O. Perez (2001), GPS estimate of relative motion between the Caribbean and South American plates, and geologic implications for Trinidad and Venezuela, Geology, 29, 75-78, doi:10.1130/0091-7613 (2001)029<0075:GEORMB >2.0.CO;2.

Willett, S., C. Beaumount, and P. Fullsack (1993), Mechanical models for the tectonics of doubly vergent compressional orogens, Geology, 21, 371-374, doi: $10.1130 / 0091-7613(1993) 021<0371$ : MMFTTO $>2.3 . \mathrm{CO} ; 2$

Yoris, F., and M. Ostos (1997), Petroleum geology of Venezuela, in Well Evaluation Conference, edited by J. M. Singer, pp. 1-40, Schlumberger Oilfield Serv., Caracas, Venezuela.

M. A. Bermúdez, Laboratorios de Termocronología y Geomatemáticas, Escuela de Geología, Minas y Geofísica, Facultad de Ingeniería, Universidad Central de Venezuela, Caracas, Venezuela. (mauricio. bermudez@ing.ucv.ve)

M. Bernet and P. A. van der Beek, Laboratoire de Géodynamique des Chaînes Alpines, Université Joseph Fourier, BP53, F-38041 Grenoble, France.

B. P. Kohn, School of Earth Sciences, University of Melbourne, Melbourne, Vic 3010, Australia.

P. B. O'Sullivan, Apatite to Zircon, Inc., 1075 Matson Rd., Viola, ID 83872-9709, USA. 